Interdisciplinary Disability Studies

\title{
DISABILITY AND NEOLIBERAL STATE FORMATIONS
}

Karen Soldatic

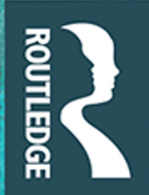




\section{Disability and Neoliberal State Formations}

Disability and Neoliberal State Formations explores the trajectory of neoliberalism in Australia and its impact on the lives of Australians living with disability, including Aboriginal and Torres Strait Islander peoples. It examines the emergence, intensification and normalisation of neoliberalism across a 20 -year period, distilling the radical changes to disability social security and labour-market law, policy and programming, and the enduring effects of the incremental tightening of disability eligibility carried out by Australian governments since the early 2000s.

Incorporating qualitative interviews with disabled people, disability advocates, services and the policy elite, alongside extensive documentary material, this book brings to the fore the compounding effects of neoliberal reforms for disabled people's well-being and participation. The work is of international significance as it illustrates the importance of looking beyond the UK, European Union and the USA to critically understand the historical development and policy mobility of disability neoliberal retraction from smaller economies, such as Australia, to the global economic centre.

Karen Soldatic is an Australian Research Council Discovery Early Career Researcher Award / Senior Research Fellow (2016-2019) at the Institute for Culture and Society at Western Sydney University. She was awarded a Fogarty Foundation Excellence in Education Fellowship for 2006-2009, a British Academy International Fellowship in 2012 and a fellowship at The Centre for Human Rights Education at Curtin University (2011-2012), where she remains an Adjunct Fellow. Her research on global welfare regimes builds on her 20 years of experience as an international, national and state-based senior policy analyst, researcher and practitioner. She obtained her PhD (Distinction) in 2010 from the University of Western Australia. 


\section{Interdisciplinary Disability Studies}

Series editor: Mark Sherry, The University of Toledo, USA

Disability studies has made great strides in exploring power and the body. This series extends the interdisciplinary dialogue between disability studies and other fields by asking how disability studies can influence a particular field. It will show how a deep engagement with disability studies changes our understanding of the following fields: sociology, literary studies, gender studies, bioethics, social work, law, education, or history. This ground-breaking series identifies both the practical and theoretical implications of such an interdisciplinary dialogue and challenges people in disability studies as well as other disciplinary fields to critically reflect on their professional praxis in terms of theory, practice, and methods.

\section{Forthcoming:}

\section{International Perspectives on Teaching with Disability}

Overcoming Obstacles and Enriching Lives

Edited by Michael S. Jeffress

Disability, Gender and Violence over the Life Course

Global Perspectives and Human Rights Approaches

Edited by Sonali Shah and Caroline Bradbury-Jones

Film, Comedy and Disability

Understanding Humour and Genre in Cinematic Constructions of Impairment and Disability

Alison Wilde

Disability and Music Performance

Alejandro Alberto Téllez Vargas

Disability and Neoliberal State Formations

Karen Soldatic

For a full list of titles in this series, please visit www.routledge.com/series/ ASHSER1401 


\title{
Disability and Neoliberal State Formations
}

\author{
Karen Soldatic
}


First published 2019

by Routledge

2 Park Square, Milton Park, Abingdon, Oxon OX14 4RN

and by Routledge

711 Third Avenue, New York, NY 10017

Routledge is an imprint of the Taylor \& Francis Group, an informa business

(C) 2019 Karen Soldatic

The right of Karen Soldatic to be identified as author of this work has been asserted by her in accordance with sections 77 and 78 of the Copyright, Designs and Patents Act 1988.

All rights reserved. No part of this book may be reprinted or reproduced or utilised in any form or by any electronic, mechanical, or other means, now known or hereafter invented, including photocopying and recording, or in any information storage or retrieval system, without permission in writing from the publishers.

Trademark notice: Product or corporate names may be trademarks or registered trademarks, and are used only for identification and explanation without intent to infringe.

British Library Cataloguing-in-Publication Data

A catalogue record for this book is available from the British Library

Library of Congress Cataloging-in-Publication Data

A catalog record for this book has been requested

ISBN: 978-1-4724-6018-9 (hbk)

ISBN: 978-1-315-57731-9 (ebk)

Typeset in Times New Roman

by codeMantra 
For my grandmother, my mother and my daughter 


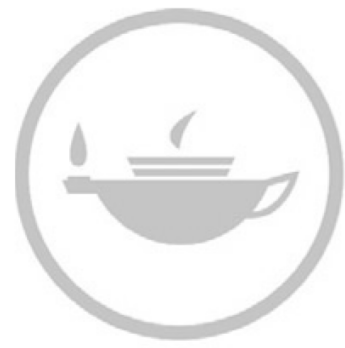

Taylor \& Francis
Taylor \& Francis Group http://taylorandfrancis.com 


\section{Contents}

List of figures $\quad$ ix

Acknowledgements xi

Abbreviations and acronyms $\quad \mathrm{xV}$

1 Introduction: disability and Australian state formations 1

2 Technologies of disability reclassification 19

3 Moralising the disabled subject: resentment, disgust and shame

4 Neoliberalising disability temporal relations 64

5 Indigenous disability in regional Australia 96

6 Conclusion: disability and the neoliberal state 117

References 135

Index 157 


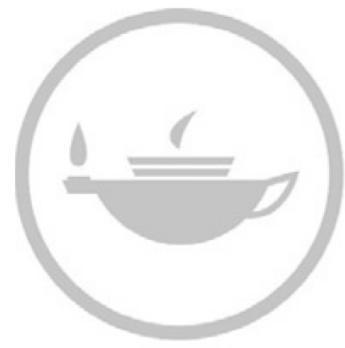

Taylor \& Francis
Taylor \& Francis Group http://taylorandfrancis.com 


\section{List of figures}

2.1 Staff support hours per client of disability employment programme, Western Australia, 1998-2004

2.2 Weekly hours of work per disabled worker, 1998 and $2004 \quad 26$

2.3 Newstart allowance recipients with partial capacity to work, 2006-2012 


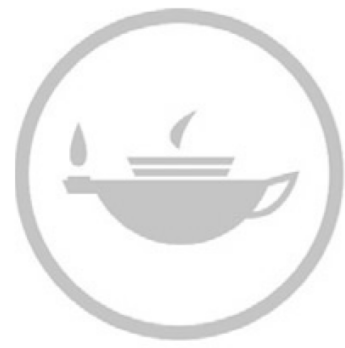

Taylor \& Francis
Taylor \& Francis Group http://taylorandfrancis.com 


\section{Acknowledgements}

First, I would like to acknowledge the research participants who have agreed, over the last 15 years, to participate in this research from across Australia. They have all given their time in the hope that this research will enable a more socially just system that garners social solidarity, respect and recognition through sharing their stories and ongoing struggles in navigating the emergence, intensification and normalisation of neoliberal workfare. A number of disability advocacy and service organisations across the country have also been highly supportive, and I particularly would like to thank their staff for their continued commitment to this research. This includes Wendy Rose, Jenny Au Yeong, Rayna Lamb, Lucia Yu, Stephen 'Baamba' Albert, Marie Shinn, Marlena Kahika, Beverley Moreton, and Nihal and Zel Iscel. Through this research you have welcomed me into your homes, fed me, supported the work and openly offered enduring friendships. On this note, a special thank you to Helen Errington, lifelong friend and persistent engaged critic, who has remained seated by my side since this project began back in the early 2000s.

I acknowledge the generous financial support that enabled me to begin this work all those years ago, particularly the Fogarty Foundation in Western Australia and the Educational Excellence Three Year funding at the early stages (2005-2009), and numerous travel grants so that the project could realise its national intent. I am also grateful to the Australian Research Council for a three-year DECRA Fellowship (2016-2019), which has enabled me to re-embark on this research journey and examine more explicitly the implications of the neoliberalising Australian state for Aboriginal and Torres Strait Islander peoples who self-identify as living with a disability.

Over the years a network of colleagues, friends and scholars have been extremely generous with their time and energy, providing ongoing support to this project. Special thanks to Anne Chapman, who spent hours labouring over the research as my supervisor, always offering important challenges to the research; Nicole Stiles for her critical eye in the early iterations of this work; Carol Thomas and Helen Meekosha, who provided rich feedback as examiners of my $\mathrm{PhD}$, which enabled me to further conceptually develop the project, providing a strong foundation for the latter years in the analysis 
and framing; and Linda Briskman, Lucy Fiske, Caroline Fleay and Barbara Pini, who supported my initial 'trialling and testing' of academic life via a secondment to the Centre for Human Rights Education, Curtin University, in 2010. I especially want to acknowledge my incredible colleagues at the Disability Services Commission, Western Australia - Jenny Perkins, David Hounsome, Anne Lawson, Lynn Selepak, Francine Holder, Dianne Shepherd, Janet Parker, Judith Chernysh and Charles Duffil - for the years of incredible commitment and faith in the possibilities of the research when I began working in this policy space and for never being hesitant to offer strong critique and robust dialogue with collegiality, love and friendship.

This project has also benefited from extensive discussions with Shaun Grech, Niro Kandasamy, Chris Grover, Donna Reeve, Hannah Morgan, Mark Sherry, Alan Roulstone, Colin Barnes, John Gilroy, Imogen Tyler, Louise Fitzgerald, Marta Celleti, S. Janaka Biyanwila, Tim Rowse and Kelley Johnson, and the critical scholarship and collegiality of Gerard Goggin, Klaus Serr, Terri-Anne White, Greg Noble, Alan Morris, Shaun Wilson, David Mitchell, Sharon Snyder, Dan Goodley, Robert McRuer and Andrew Sayer.

I would also like to acknowledge the careful and thoughtful editing carried out by Kelly Somers and her dedication and commitment to the project over the years. You have waited patiently for every change, edit and, sometimes, even just some type of 'movement' as I slowly worked through the manuscript, and for reordering my disorder. Thank you.

Finally, I thank the publishers who gave permission, allowing me to republish some of the work produced over the years that, combined, makes this book possible. Excerpts in this book have previously appeared in the following publications:

Karen Soldatic and Barbara Pini 2009, 'The three Ds of welfare reform: disability, disgust and deservingness', Australian Journal of Human Rights, 15 (1), 77-95. Copyright (C) Australian Human Rights Centre, reprinted by permission of Taylor \& Francis Ltd, http://www.tandfonline.com on behalf of Australian Human Rights Centre.

Karen Soldatic and Anne Chapman 2010, 'Surviving the assault? The Australian disability movement and the neoliberal workfare state', Social Movement Studies, 9 (2), 139-54. Reprinted by permission of Taylor \& Francis Ltd.

Karen Soldatic 2011, 'Appointment time: disability and neoliberal workfare temporalities', Critical Sociology, 39 (3), 405-19. Copyright (C) 2011 by the Author. Reprinted by permission of SAGE Publications, Ltd.

Karen Soldatic and Helen Meekosha 2012, 'The place of disgust: disability, class and gender in spaces of workfare', Societies, 2 (3), 139-56. doi: 10.3390/soc2030139. (C) 2012 by the authors; licensee MDPI AG, Basel, Switzerland. This article is an open-access article distributed under the terms and conditions of the Creative Commons Attribution License (http:// creativecommons.org/licenses/by/4.0/). 
Karen Soldatic and Hannah Morgan 2017, “The way you make me feel”: shame and the neoliberal governance of disability welfare subjectivities in Australia and the UK', in J Louth and M Potter (eds) Edges of identity: the production of neoliberal subjectivities, 106-33. Chester: University of Chester Press. Reprinted by permission of University of Chester Press.

Karen Soldatic 2017, 'Policy mobilities of exclusion: implications of Australian disability pension retraction for Indigenous Australians', Social Policy and Society, 17 (1), 151-67. Reproduced with permission from Cambridge University Press. 


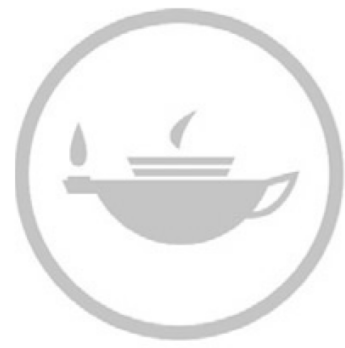

Taylor \& Francis
Taylor \& Francis Group http://taylorandfrancis.com 


\section{Abbreviations and acronyms}

\begin{tabular}{|c|c|}
\hline ACE & Australian Competitive Employment \\
\hline ACOSS & Australian Council of Social Service \\
\hline ACROD & Australian Council for Rehabilitation of the Disabled \\
\hline AIRC & Australian Industrial Relations Commission \\
\hline APA & Australian Parent Advocacy Inc. \\
\hline DEAC & Disability Employment Action Centre \\
\hline DEWR & Department of Employment and Workplace Relations \\
\hline DPA & Disability Participation Alliance \\
\hline DPOs & Disabled People's Organisations \\
\hline DSP & Disability Support Pension \\
\hline DSS & Department of Social Security \\
\hline $\mathrm{FaCS}$ & Department of Family and Community Services \\
\hline IMF & International Monetary Fund \\
\hline NCID & National Council on Intellectual Disability \\
\hline NHSNN & National High Support Needs Network \\
\hline OECD & Organisation for Economic Co-operation and Development \\
\hline PWD & Australia People with Disabilities Australia \\
\hline
\end{tabular}




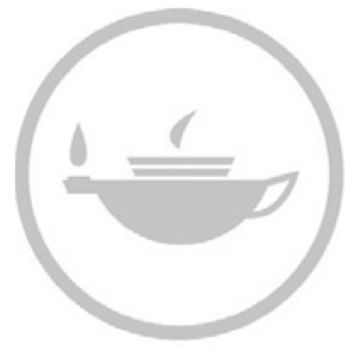

Taylor \& Francis
Taylor \& Francis Group http://taylorandfrancis.com 


\section{Introduction}

\section{Disability and Australian state formations}

Societal notions of the body are located in time and space, and the sociopolitical environment of the day. Stone's (1981) seminal work on the Disabled State reveals the extent to which the emergence of the modern capitalist nation relies on the reclassification of the human body. In seeking out the mechanisms that classify and mark out bodies as disabled within state formations, this book examines disability as a socially constitutive collective class and identity with the emergence of the postmodern, neoliberal nation state. It builds on spatial-temporal, socio-relational arguments to identify disability and disablement as socially produced and reproduced oppression. In this book I explore those mechanisms that are integral to the consensus-building project occurring as neoliberalism grows in power and the strategies drawn upon to build popular support for the reconstitution of 'disability' under the neoliberal workfare state.

Disability has always been an integral part of the making of the Australian nation (Jakubowicz and Meekosha 2002). As disability scholars have theorised, the relationship between ethnicity, race and disability has underpinned the nation-building strategies of white settler societies, such as Australia (Jakubowicz and Meekosha 2002; Meekosha 2005). The formation of a White Australia, as a national 'body' politic, was the 'confluence of border controls and public health measures, underpinned by medical science' (Jakubowicz and Meekosha 2003, p. 180) and supported by the international hygiene movement, more commonly known as eugenics (Bashford 2004; Wyndham 2003). At the turn of the 20th century, eugenics, as science, medicine and social regulation, was a governing rationality (Baker 2002) and of strategic importance to the imperial colonial project (Bashford 2004). Promoting a range of mechanisms 'based upon scientific management systems' (Mitchell and Snyder 2003, p. 844) was central to excluding those bodies seen as inferior, unfit and impure in achieving 'national fitness' (Wyndham 2003). The Immigration Restriction Act (1901), well known for its racialisation of border controls, also marked out 'any idiot or insane person' or 'any person suffering from an infectious or contagious disease of a loathsome or dangerous character'. The impaired immigrant, represented as a burden to the state (Gothard 1998), was a focus of powerful moral 


\section{Introduction}

discourses and practices situating whiteness as moral biological purity, free from contagion (Soldatic and Fiske 2009).

Many second- and third-generation Australians like myself bear the stamp of these racialised and disabling ideologies and practices. My maternal grandmother was placed in institutional care during the height of the eugenics period in the 1940s and remained incarcerated until her death almost 40 years later. With my grandmother deemed unable to care for her children, my mother and her siblings were removed to an institution and then permanently placed in foster care with a white working class Australian family in the suburbs of western Sydney. As a result, my mother's existence has been a site of relentless negotiation. In addition to the institutionalisation of her childhood, the constant emotional upheavals of attempting to reconcile my maternal grandmother's 'madness' has shaped my mother's existence in both her cultural community and the broader community of White Australia. The internalisation of having to constantly defend one's integrity in these racialised and disabling environments has been mutually constitutive (Yuval-Davis 2007, p. 565), having a profound effect on my mother's subjectivity, her sense of self and, of course, her own parental practices of care. ${ }^{1}$

As a child, I never really understood the significance of these practices of subjectivity and identity formation. I realised at school that I was 'different' but assumed this was associated with my parents' class and ethnic identity. It was not until more recently that I understood more clearly the relationship between my grandmother's disabled identity and my family's significant difference in both the Croatian migrant community and her new White-Australian family. The deep anguish associated with attempts to selfregulate the constant emotional barrage of love and shame shrouded not only my mother's being but how we were socialised, and thought of, by others.

At the age of eight, I was finally allowed to visit the institution where my grandmother lived. I often recall the car trip and the attendant pride I felt in learning that I had three grandmothers and not just two. The prospect of meeting another grandmother was completely exhilarating to me, and I recall running into her room to introduce myself - only to be told to 'slow down' and 'be quiet'. Inevitably, my feelings of excitement gave way to confusion and bewilderment. By the end of the visit, I was overwhelmed with disappointment. My eight-year-old self was frustrated by her unwillingness to look at or even talk to me as well as angry that this was not the mysterious third grandmother I had hoped to brag about at school. I kept wondering why she could barely speak in any language, let alone English, and why she refused to look at me. It is this moment on which I always reflect.

I now understand that her behaviour was an outward manifestation of the toll that long-term incarceration had taken on her soul (Rose 1999), which was likely exacerbated by the extensive use of so-called therapeutic interventions (Jarman et al. 2002). I often wonder about the possibilities that may have awaited my grandmother as an individual had her circumstances 
been different, and also on imagining the different journey that could have been for all of us had there not been so much social stigma attached to her 'mad' existence. On reflection, I am now inclined to suggest that the subjectification of racialised and disabling practices passes from parents to their children (Garon 2004). ${ }^{2}$ Moreover, while we accept in sociological inquiry the role of hegemonic national cultures in racialising identities in secondgeneration immigrants (Lappalainen 2009), it may be that the disabled subjectivity is similarly intergenerational, as other authors, such as Lennard Davis (1995), have previously suggested. This process of embodiment has shaped who I am, and it is this political subjectivity that determines the framing of this research.

This book, however, is not an auto-ethnographic one. My motivation here is different and emerges from my worker identity within the 'disability industry'. The journey of this research began when the service provider I worked for participated in the first round of federally funded trials to move civil society providers from block funding to outcomes-based funding. Being part of this trial made me acutely aware of the kinds of practices that were emerging in the social field due to new funding restraints and of the resultant effects on social relations between workers and disabled jobseekers. As a worker, it appeared to me that 'disability' and who was defined as disabled were being reconstituted. The body appeared to be undergoing a new process of social stratification as I repeatedly observed service workers and management selectively divide, sort and classify individuals into those who could meet the trial's funding outcomes and those who could not. Questions such as which bodies were worthy of social investment through publicly funded services and what types of service they should receive were disregarded in some instances but heavily contested in others.

In every attempt to answer these questions, I was aware that part of my own humanity and possibly my concern for other human beings was being slowly eroded. As a service worker and human being, I developed significant concerns about the role of publicly funded service provision and citizenship rights. If citizenship is underpinned by notions of rights and entitlements (Barbalet 1998; Stainton 2002) then, within the new funding regime, consideration of one's right to treatment with dignity and respect becomes paramount (White 2004). In the new funding environment, however, it was precisely this right that appeared to be under greatest threat. As Nussbaum $(2001,2004)$ argues, social institutions play a vital role in our quest to reach our full capacity as human beings. It follows, then, that institutions also have the power to undermine and dismiss our human potential; disability employment services is one such institution. Governed by legal frameworks and funded publicly, disability employment providers purport to represent the interests of disabled people in reaching their full potential by supporting their participation in the labour market as a means to redress their severe levels of material disadvantage and dependent class status. It was this quest for exploring what it takes to be human (Archer 2000; Nussbaum 2001, 


\section{Introduction}

2004, 2007) that led me beyond the general policy debates on 'welfare to work' to what social theorists such as Sayer (2000a, 2001) have attempted to renew in the exploration of the moral economy of society. They suggest that processes of moralisation are deeply embedded in political representation and that these forms of representation move from macrostructures to shape and frame micro-social relations of everyday life. It is the link between macrostructural processes of moralisation in the development of one's identity and the subjective experience of the 'self' within this context that this book seeks to explore.

\section{Thinking through disability: theoretical framings}

Although the disability studies field has a fairly recent history within sociological inquiry, it is already contested terrain. Critical disability studies emerged from the disability movement's standpoint and response to Western medical models of disability. It can be broadly split into two main strands of theorising: idealist theories and materialist accounts of disability. Casting disability analysis within a social frame, idealist theories have been highly influential in theorising the relationship between the impaired body and society, hereby demonstrating the significance of power relations, particularly between institutions, professionals and disabled people (see Tremain 2005), and cultural representations of the impaired/disabled body (see Garland-Thomson 1996, 1997; Murray 2008; Riddell and Watson 2003; Siebers 2002). Drawing on the work of Goffman (1963), and more recently Butler (1993, 1999), Foucault (1970, 1973, 1977, 1989) and Rose (1996, 1999), this body of work emphasises the role of social attitudes, aesthetics, cultural discourses, discursive structures and representation in determining and conditioning the social experience of living with an impairment. While Foucault may have objected to being termed an idealist rather than a cultural materialist, the focus of his work in these idealist theoretical accounts is exclusively within the domain of discourses and the cultural realm. In nearly all these works, disability is viewed as a social construct that arises in line with modern medical discourses on body and minds and, in its most extreme form, the body is seen as a social text requiring deconstruction (see Galvin 2004b; Rapley 2001). Actively questioning the 'master narrative of the body' (Sennett 1994, p. 15), this work has sought to deconstruct and problematise the medical discourses and discursive structures that 'come to be internalised by disabled people' (Snyder and Mitchell 2006, p. 7). Idealist analysis is thus focussed on the making of the disabled subject, grounded in identity politics and the struggle for recognition (Lawson 2001).

Many disabled people, however, object to the extreme form of cultural constructivism of the body that underpins many idealist accounts of disablement (Abberley 1991), arguing that there is a 'materiality to social practices' (Gleeson 1999, p. 21). In line with the growing number of disabled people who have called for the recognition of impairment as a real 
ontological state, there is a need to theorise the material practices that disable impaired people in everyday life, in addition to those cultural discourses and discursive structures that constitute normate-disabled relations. Such an argument seeks to separate and ensure that the ontological reality of our bodies is not conflated with discursive epistemological construction of its meaning in everyday life and practice (Williams 1999). Materialist theorising on disability first emerged from the scholarship of disability activists in the UK (Abberley 1987, 1991, 1999, 2002; Barnes and Mercer 2003, 2005; Finkelstein 1980, 2001; Oliver 1986, 1990, 1996; Thomas 2002, 2004, 2007). In conceptualising what disability is, these activists/scholars have argued that impairment should be defined separately from disability in order to shift the focal point of analysis from the medical diagnosis of the body to those societal structures that disable, exclude and oppress people with impairments (Thomas 2004). Mike Oliver's definition, probably the most cited in both activist and scholarly work, conceptualises the distinction between impairment and disability as:

Impairment, lacking part of or all of a limb, or having a defective limb, organism or mechanism of the body;

Disability, the disadvantage or restriction of activity caused by a contemporary social organisation which takes no or little account of people who have physical impairments and thus excludes them from the mainstream of social activities.

(Oliver 1990, p. 11)

Materialists conceptualise disability as produced through the social relations of society (Abberley 1999; Barnes 1997; Barnes and Mercer 2005; Clear and Gleeson 2001; Gleeson 1999; Oliver 1990; Russell 1998, 2001; Thomas 1999).

Materialist theorising on disability has illustrated the historical link between the capitalist mode of production, the commodification of labour and the management of impaired bodies within this context, and the relationship of those bodies to state-regulating regimes (Gleeson 1997, 1999; Oliver 1990). With the capitalist appropriation of surplus value from the production process, those who are not able to meet the production demands of society have been increasingly marginalised (Russell 2001). From a Marxist theory of surplus value, the exploitation of labour is achieved through the expropriation of surplus labour, that is, the differential value of wages paid to the value of the commodity sold in the market place (Wood 1995). The rise of industrial capitalism brought with it changing work practices and a restructuring of the production process, creating conditions for a pool of 'uncompetitive workers who were eventually incarcerated in the new institutional system of workhouses, hospitals and asylums' (Gleeson 1997, p. 195). Drawing on Marx's conception of nature, Gleeson (1999, p. 53) defines impairment as first nature and disability as second nature in order to 


\section{Introduction}

articulate the way societies produce and reproduce structures that condition and 'transform impaired first nature as disablement'. For this group of theorists, the focus is on the politics of distribution to identify the necessary social and institutional measures of egalitarian redistribution required to redress those social injustices that disable impaired people in an unjust capitalist political economy. Within the capitalist political economy, work and the labour process represents the key area of struggle for social equality, citizenship and material well-being (Abberley 1996, 1999, 2002; Barnes 1999; Barnes and Mercer 2005; Grover and Piggott 2005; Roulstone and Barnes 2005; Thornton 2005).

Increasingly, however, divisions between materialist accounts of disablement and the struggles within the cultural realm are being contested (Butler and Parr 1999; Danermark and Coniavitis Gellerstedt 2004; Jakubowicz and Meekosha 2002; Mladenov 2017). Many disabled feminists have argued extensively that the insights offered by materialism cannot account for the gendered component of the disabled identity (see Crow 1996; Fine and Asch 1988; Ghai 2003; Meekosha 2002; Morris 1991; Wendell 1996, 2001). Challenging both materialist and idealist conceptualisations, it appears ever more plausible to argue that disability is a social collectivity of complexity, that the struggles for recognition and egalitarian redistribution are deeply intertwined and that representational politics is a central component of this regulating nexus which is often not captured in critical depth. Conceptualisations of disability need to account for the intertwining constitutive practices of the three Rs - the politics of representation, redistribution and recognition - in disabled people's struggles for justice, rights and social affirmation. Importantly, this picture reveals that state-regulating regimes of disability anchored in Western normative notions of the body depict a dialectical relationship between the cultural symbolic role of disability and capitalist class relations that position disability as a dependent group, on the one hand, and those political representative processes that maintain state relations of power, on the other.

Fraser $(1995,2007)$ refers to social collectivities as bivalent, where the process of social oppression and subordination is structurally located in both the capitalist political economy, in forms of cultural valuation, and political representative structures of state institutional power. While Fraser's work has focussed mostly on gender, sexuality, class and race, as Mladenov (2017) has argued in relation to disability in the former socialist states of Eastern Europe, this multilayered analysis of disability as a collectivity is pivotal in bringing forth the social struggles situated within neoliberal re-regulation of disability as a state population category and its transformative effects. As Mladenov (2017) has teased out, this approach enriches the historical analysis of the significance of disability to state-regulating regimes as it effectively challenges the analysis to explore the mutually constitutive processes and mechanisms that harness normative positionalities of the human body. Such positioning elucidates the dispossession of disabled people under the 
capitalist political economy with the emergence, intensification and normalisation of neoliberal re-regulating structures of state power.

Finally, as the recent work of scholars such as Tyler (2013) have illustrated, the role of emotions as normative judgements of value has been articulated as a politicised technology building popular consensus within the polity for neoliberal re-regulation. Emotions as normative evaluative judgements act as the moral public justification for the stigmatisation and debasement of different body types (Tyler 2013). Emotions emerge from our social existence, inseparable from their broader social and cultural locations, and are interconnected with our material conditionalities (Sayer 2005). By moving to the realm of normative evaluative judgements, we are, as Sayer $(2003,2005)$ has argued, expanding the material analysis to include the realm of moral economy. To reiterate Vike (1997, p. 197), 'moral discourses are meta-discourses of power and legitimacy'. Therefore, this book hopes to illustrate the interrelationship between the cultural-symbolic realm, the political economy and moral discourses with the emergence, intensification and normalisation of disability neoliberalisation, all of which operate conjointly in a complex interplay as regulating discourses and practices (Sayer 2003; Vike 1997). From here, we can begin to theorise on a range of emotions - such as disgust, shame and resentment - that operate as meta-discourses of power which normalise the worst excesses of neoliberal dispossession and structural violence.

I argue that by theorising the affective realm of neoliberal politics and its harnessing of processes of medicalisation to socially re-regulate impaired bodies, it becomes possible to reveal a neoliberal moral economy of disability. The participants of this research reveal that neoliberal affective politics is not reducible to either the idealist or materialist accounts (Vike 1997). We can clearly establish which emotions, as normative evaluative judgements, make the dispossession of some bodies acceptable within the public realm and begin to make the theoretical link between the moral economy of disability and social relational accounts of disablement. It becomes possible to meet Thomas's $(1999,2002)$ call to expand the sociological accounts of disability to acknowledge the important role of emotions, as moral discourses of power, in transforming state regulations of disability with the hegemony of neoliberal restructuring.

\section{Neoliberal workfare: the new state formation}

Neoliberalism is often described as a system of governance, of economic reordering, that legitimises new forms of capitalist maldistribution from the poor to the rich, coupled with an ideological mapping that trumps the individual over collective concerns of the good, the just, inequality, poverty and deprivation. Its most transformative effect is the normalisation of new forms of citizen dispossession and abjection (Tyler 2015).

The global beginnings of neoliberalism as a real, material, ideological political possibility arose in the 1970s with the breaking of the old world order, 


\section{Introduction}

established at the end of the Second World War among Western powers, to impose new forms of global economic power under the tensions of Cold War politics. In Australia the neoliberal moment occurred around 1975, by which time the national Labor government had begun to disband its commitment to socially just redistributive social provisioning (Cass 2005) due to a deep economic recession, triggered by the growing Fordist crisis of production that led globally to an exponential rise in unemployment (Peck 2001). The enduring fiscal crises of the state, elaborated through a political discourse of statistical panic to garner broadscale popular support, led to a highly divisive change of government. The new Coalition government set about actively discrediting the prevailing Keynesian hegemony (Shaver 1989). Neoliberalism was slowly secured through incremental reforms by both conservative and Labor governments over the next 20 years, and intensified under the radical conservatism of the Coalition government of 1996-2007. Prime Minister John Howard instigated a widespread campaign to advance neoliberal social policy measures across all spheres of social life (Bessant et al. 2006), leading to the dismantling of rights for a diverse range of social groups, including women, refugees, people with disabilities and Indigenous Australians (Carney 2003, 2006; Maddison 2008; Parker 2007; Penovic and Dastyari 2007; Nevile 2008). Neoliberalism has since become normalised as policy convention across all areas of Australian life (see Serr 2017). Incremental refinement of neoliberal disability governance has occurred with broadscale political support, even against moments of public contestation.

The emergence of neoliberalism, with its focus on retracting state redistributional power alongside harnessing the labour power of citizens, that is, putting individuals to work, coalesces with the rise of the disability rights movement for equality and economic participation on a par with socalled able-bodied citizens (Roulstone and Morgan 2009). As French and Swain contend (2008), while these two movements have disparate aims for disabled people, their focal point around disabled people's enduring inequality, perpetuated through disabled people's exclusion from the labour market and the resultant effects of entrenched poverty and dependence on welfare, has at times led to an uncomfortable convergence (Soldatic and Meekosha 2012). Neoliberalism's foregrounding of economic participation via the labour market as a duty of citizenship (Bessant 2000; Goodin 2002; Peck 2001; Skeggs 2004; Schram et al. 2008) is, however, quite distinct from the disability movement's claim for the right to work (Grover and Piggott 2010; Malhotra 2006; Roulstone and Barnes 2005; Soldatic and Pini 2012; Zames Fleischer and Zames 2001). Disability activism has targeted policies of redistribution, the political sphere of representation and the affirmative realm of identity recognition and affirmation for disabled people's citizenship, whereas neoliberalism has advanced strategies of de-democratisation by enforcing economic participation through various forms of compliance, coercion and welfare compacts. 
Nearly all Western liberal democracies have undertaken large-scale disability policy restructuring in line with neoliberal welfare policy trends. While there is a multiplicity of local variations and deviations, international policy converges around the restructuring of disability social security entitlements, with the primary aim of steering disabled people off disability pensions and into the open labour market (Grover and Piggott 2010). 'Workfare', in its full articulation, first surfaced in North America under the Reagan administration but came into full effect in the US during the Clinton administration with the passage of the Personal Responsibility and Work Opportunity Reconciliation Act 1996 (Abramovitz 2006, p. 339). Workfare is now part of an international project (Haylett 2003, p. 765) promoted through global policy institutes such as the OECD and IMF (Humpage 2007, p. 220). In the UK, the Blair Labour government developed its 'making work pay' strategy and its New Deal policy (Cook et al. 2001; Finn 2000, 2002; Peck 2001; Walker and Wiseman 2003), while Canada (Peck 2001) and Australia (Cass 2005; Castles 2001; Goodin 2002; Harris 2001, 2002; Humpage 2007; Shaver 2001) have taken similar paths. Considine (2001) has argued that Australia appears to have taken the most radical path of all in reforming its welfare institutions, and in turn, inequality is now greater than at any other time in Australia's history (ACOSS 2016).

Workfare restructuring has established new understandings of citizenship (Shaver 2002). Citizenship 'rights and entitlements' have been redefined as citizenship 'responsibilities and obligations' (Goodin 2002); this reconceptualisation is reflected in the neoliberal populist mantra of "no rights without responsibilities' (Fiske and Briskman 2007). Under this policy framework, access to social entitlements is no longer based on need or necessity. Citizens receiving welfare are forced to earn their social entitlements through participation in the labour market (Peck 2001) as paid work is promoted as the highest form of citizen responsibility (Lister 2001).

The centrality of work within neoliberal workfare citizenship debates is constructed on able-bodied, masculine notions of care, work and productivity. The core of the neoliberal argument is that any job, no matter its conditions, hours or pay is a job worth having (Peck and Theodore 2000). For many disabled people who have extensive personal care needs, and especially in the case of women with disabilities who may provide multiple forms of care for themselves and others, workfare is a highly pervasive policy strategy further stigmatising the subjective experience of the self and the body. Care for the nation, exhibited through performing paid work within the labour market, becomes the highest form of citizen responsibility (Soldatic 2013), while people receiving welfare who perform care for themselves and for others are denied the validity of this form of social participation (Haylett 2003; Frohmader et al. 2014; McInnes 2007). Shaming into compliance is a common feature of the coercive regulating regime (Soldatic and Morgan 2017). As legitimising discourse, neoliberal workfare not only individualises but also directly blames those who are suffering from 
structural disadvantage (Tyler 2013). The lack of a job is articulated as a private moral failure. Moralising structural disadvantage reinforces existing social divisions (Martin 2007) while reconstituting new social hierarchies. For disabled people, the deliberate 'misrecognition' of their structural exclusion from the labour market further entrenches their enduring position of poverty, which is more pronounced for women with disabilities and Indigenous Australians living with disability (Soldatic and Sykes 2017). Other discriminatory issues, such as accessible transport or personal care support within the workplace that facilitate disabled people's employment participation, are rarely acknowledged in workfare debates (Soldatic and Sykes 2017).

To borrow from Peck (2001) and express this in Foucauldian terms, disabled people are the new bodies and minds forced into an even more open, precarious and unprotected labour market. Neoliberal workfare's main aim is to pull the floor out of the bottom of wages by enforcing labour market participation through a new range of state regulatory controls and compelling surplus labour into the discipline of the market (Peck 2001). Catchwords such as flexibility, casualisation and productivity are coupled with discourses of mutual obligation. In Australia, the Howard government's legislative amendments to disability social entitlements and social provisioning fully articulated the neoliberal reimagining of welfare as workfare (see Carney 2006). Labour market flexibility, casualisation and worker insecurity, driven by the neoliberal contract of market rule, has dramatically affected disabled Australians, as exemplified by the narratives of the disabled people articulated in this book.

\section{Significance of this book: disability and neoliberal workfare}

This research makes a substantial and original contribution on a number of fronts, namely, critical disability studies, workfare studies and policy analysis. There is limited knowledge of how civil society agents stand in relation to the state, the market and disabled actors (both collectively and individually) in terms of the policy process. According to Burawoy (2003), civil society can collaborate with the state to contain sites of socio-political economic struggle, or they can have enough autonomy to promote dissent, contestation and mobilisation. As the state increasingly applies market terms to deliver its social policy outcomes (Ramia 2002), there is a pressing need to understand how the growing application of state contractualism with civil society organisations unfolds under workfare regimes. Jayasuriya (2002, p. 309) argues that this is a 'distinctive form of contractual governance', wherein social policies are contracted through a 'chain-of-contracts'. Disability employment services, civil society organisations now responsible for the monitoring of disabled people's compliance with neoliberal contractual governance, are an integral part of this chain. Over time, Australian governments of both persuasions have implemented new legislated forms of citizen control and surveillance via the realm of service compliance contracts. 
This process of contractual governance has implications for disabled people and their sense of self as the resultant practices begin to reconstitute their individual and collective identities, and ultimately impact upon their material and subjective well-being, as described in later chapters.

Moreover, there is limited research on the effects of neoliberal workfare contractual governance on movement politics, collective representation and participation within the Australian political sphere (Maddison and Martin 2009). The silencing of dissent through disengaging with collective politics has been a key battleground for neoliberal governance (Harvey 2005), and, in the Australian context, 'the anti-democratic excesses of the Howard era have been well documented' (Maddison and Martin 2009, np). In fact, as neoliberal market orthodoxies become central to state-citizen relations, the individual becomes elevated 'as a market agent, pursuing advantage in competition with others' (Connell 2008, p. 247, original emphasis). Rendering collective struggles for justice as futile, neoliberal governance and regulatory processes actively delegitimise civil society collective agents as a central part of democratic governance (see Maddison and Hamilton 2007).

The Australian disability movement's collective struggles for justice are not exempt from these silencing strategies (Soldatic and Chapman 2010). The movement in Australia, part of a global disability rights movement, emerged in the late 1960s. Founded on a common identity (Meekosha 2002, p. 72), the movement was forged with the collective 'experience of discrimination and difference' (Smith 2003, p. 345). It reframed 'disability' from a site of abjection, medicalisation and biological inferiority to a site of social oppression and politics (Newell 1996). The strength of this reframing empowered disabled people to work collectively to contest the hegemonic practices that positioned them as the deserving poor, worthy of pity and charity. As Zames Fleischer and Zames (2001) report in the US context, the Australian disability movement directly confronted, and continues to confront, dominant and unquestioning signified representations of disabled people and 'self-serving assumptions about normality' (Meekosha 2002, p. 69). Yet, as this book reveals, this collective agency to resist welfare restructuring has come increasingly under pressure from a neoliberalising state that seeks to delegitimise the disability movement's claims for justice, rights and recognition.

The Australian disability movement made large gains for social rights, including social security, anti-discrimination legislation and disability policy representation, during its pinnacle period of activism in the 1980s. Segments of the movement became formalised as institutional actors (Newell 1996, pp. 429-32). Disability advocacy organisations were established around the country, giving greater 'voice' to disabled people in local policy debates. As a consequence of this representation, new services, largely governed by disabled people, were established around the country. However, the arrival of the Howard government and the closing down of dissent across the Australian polity (Maddison and Hamilton 2007) represented a period of 


\section{Introduction}

intense retraction of the rights of people with disabilities, along with other groups outside the government's cultural commemorations of a white, ablebodied nation (Greenfield and Williams 2003; Jakubowicz and Meekosha 2003). By 1999, as a reflection on the Australian disability movement's gains and losses, leading disability feminist Helen Meekosha (1999, p. 1) argued that for many disabled people, living in Australia at the turn of the century was like living in a 'war zone'. Gerard Goggin and Christopher Newell (2005), two leaders of the Australian movement, concurred with this position, articulating 'disability' as a state of social apartheid.

As outlined in the following chapters, many of the gains made during the 1980 s were actively wound back with the advent of neoliberalism as the governing hegemonic ideology of the nation state. With neoliberalism's intensification, the movement's institutionalisation became further entrenched as advocacy groups were embedded within state contractual relations, which sought to actively constrain their representational actions. Such groups were increasingly reframed by the Howard government as political lobbyists rather than civil society actors, actively denying disabled people their collective potential for dissent and mobilisation (Maddison and Hamilton 2007), and causing them to lose ground on many of their previously hard-won gains. Despite the intense pressure from the neoliberal state, the Australian disability movement has maintained a commitment to a pluralist identity politics (Cooper 1999, p. 217). The unifying principle of mobilisation has been around the 'common need to raise a voice against hegemonic power structures' (Meekosha and Dowse 1997, p. 65). Struggles for justice are centred on issues of representation. Representational politics, in this context, envisages the multiplicity of democratic spheres, both private and public, that are central to disabled people's emancipatory struggles for rights and justice. This book reveals the significance of the disability movement and its collective efforts in its struggle to realise differing avenues to further disability justice claims.

To counter disability restructuring and social provisioning retraction, the Australian disability rights movement has undergone processes of abeyance, contraction and expansion. In particular, Indigenous Australians living with disability have formed their own advocacy and activist networks, often in partnership with Australian disabled people's organisations (DPOs). Working at the interstice of the ensemble of neoliberal policy regimes to further their claims for justice, they demand redistributive measures via the category of disability partly to seek recognition for the long-standing exclusion of Aboriginal and Torres Strait Islanders from disability welfare regimes and partly as a direct response to the production of disability as an outcome of white settler colonial governance and Indigenous dispossession. Aboriginal and Torres Strait Islander peoples living with disabilities yet remain significantly under-represented in disability redistributive measures (Productivity Commission 2011), despite these growing efforts to open up and gain recognition for disability within Indigenous Australia. 
In the realm of Indigenous policy, it is now well documented that Aboriginal and Torres Strait Islander peoples have experienced the worst excesses of neoliberal workfare conditionality (Marston et al. 2016). Indigenous specific policies have seen the implementation of mechanisms to control all areas of Aboriginal and Torres Strait Islander individual behaviours in line with neoliberal commitments around work, employment and social security. Paternalistic governance of social security payments through 'cashless transfer systems' and the ongoing monitoring of participation in Indigenous employment programmes, alongside the open competitive tendering of Indigenous service provision to bring in non-Indigenous private providers, are some of the new forms of colonial governance that ensure large-scale compliance to neoliberal workfare systems (Jordan 2018). There has not yet been a grounded theoretical analysis of the impact of disability social security reform on redistributing disability mechanisms to enhance subjective, material and cultural well-being with the shift to neoliberal workfare.

\section{Positioning disability, positioning disabled people: methods}

The 'site' of investigation in this research was not disabled people per se but how disability is reconstituted under the growing normalisation of the neoliberal workfare state. This analytical approach views policy process as a dynamic, open system embedded in a range of social relations, all of which shape the outcome (Sayer 1995). This approach is well accepted in critical policy studies, particularly as an analytical tool to explore the constitution of social identities within the national landscape (Bessant et al. 2006; Dalton et al. 1996; McClelland 2006; Vike 1997). It also enabled the analysis of the movement of disability across state institutional structures and the growing significance of the category of disability to differing stages of neoliberalism from emergence to intensification and, finally, the stage of normalisation. For example, arguably the most significant structural change occurred within four days of the re-election of the conservative Howard government in October 2004, when it gained control of both houses of Parliament. This change saw the Disability Employment Programme split into two distinct groups. Disability social security regulation alongside disability open labour market employment services became part of the Department of Employment and Workplace Relations, the key state institution at the time, charged with neoliberalising Australian labour market regulatory controls. Sheltered workshops remained with the primary welfare institution, named at the time the Department of Family and Community Services. Within 18 months, highly restrictive disability social security legislation was pushed through Parliament not 24 hours after changes to industrial relations legislation which brought in individualised contracts and the potential criminalisation of union activism and mobilisation. Understanding policy as process critically distils the mobility of disability reclassification technologies across 


\section{References}

Abberley, P 1987, 'The concept of oppression and the development of a social theory of disability', Disability, Handicap and Society, 2 (1), 5-19.

Abberley, P 1991, Three theories of abnormality, The Disability Studies Archive UK, Centre for Disability Studies, University of Leeds, www.leeds.ac.uk/disability-

studies/archiveuk/archframe.htm [accessed 2 February 2002 ].

Abberley, P 1996, 'Work, utopia and impairment', in L Barton (ed), Disability and society: emerging issues and insights, Harlow: Longman, 61-79.

Abberley, P 1999, The significance of work for the citizenship of disabled people, The Disability Studies Archive UK, Centre for Disability Studies, University of Leeds,

www.leeds.ac.uk/disability-studies/archiveuk/archframe.htm [accessed 2 February 2002 ].

Abberley, P 2002, 'Work, disability, disabled people and European social theory', in C Barnes , M Oliver and L Barton (eds), Disability studies today, Cambridge: Polity Press, 120-138.

Abramovitz, M 2006, 'Welfare reform in the United States: gender, race and class matter', Critical Social Policy, 26 (2), 336-364.

ABS (Australian Bureau of Statistics) 2009, Labour force: disability, cat. no. 4446.0, Canberra, ACT: ABS.

ABS 2010, Measures of Australia's progress, cat. no. 1370.0, Canberra, ACT: ABS.

ABS 2012, Australian social trends, March quarter 2012, Canberra, ACT: ABS.

ABS 2015, Disability, ageing and carers, Australia: summary of findings, cat. no. 4430.0, Canberra, ACT: ABS.

ABS 2016, National Aboriginal and Torres Strait Islander social survey, 2014-15, cat. no. 4714.0, Canberra, ACT: ABS.

ABS 2017a, 'Aboriginal and Torres Strait Islander people with disability', in Disability, ageing and carers, Australia: summary of findings, 2015, cat. no. 4430.0, Canberra, ACT: ABS.

ABS 2017b, Census of population and housing - counts of Aboriginal and Torres Strait Islander Australians, 2016, cat. no. 2075.0, Canberra, ACT: ABS.

ACOSS (Australian Council of Social Services) 2005, Information Briefing 373 2005: Welfare reform: participation or punishment, Sydney, NSW: ACOSS.

ACOSS 2016, Poverty in Australia, Sydney, NSW: ACOSS.

ACOSS 2018, Welfare "reform" briefing note, Sydney, NSW: ACOSS.

ACROD 1999, ACROD submission: reference group on welfare reform, Canberra, ACT:

ACROD.

ACROD 2004a, ACROD news, Canberra, ACT: ACROD.

ACROD 2004b, Caution required in drawing conclusions from the JobNetwork Pilot, Canberra, ACT: ACROD.

ACROD 2005, ACROD news update: AIRC issues its decision on wage regulation, Canberra, ACT: ACROD.

Adam, B 1990, Time and social theory, Cambridge: Polity Press.

Adam, B 2004, Time, Cambridge: Polity Press.

AHA (Australian Health Associates) 2000, Interim report on the case based funding trial, Canberra, ACT: Commonwealth of Australia.

AHA 2002, Complete report: case based funding trial final evaluation report, Canberra, ACT:

Commonwealth of Australia.

Ahmed, S 2004, The cultural politics of emotion, London: Routledge.

AHRC 2008, A statistical overview of Aboriginal and Torres Strait Islander peoples in Australia: Social Justice Report 2008, Sydney, NSW: Australian Human Rights Commission.

Alcock, P 1993, Understanding poverty, London: Macmillan.

Alston, M 2005, 'Social exclusion in rural Australia', in C Cocklin and J Dibden (eds),

Sustainability and change in rural Australia, Sydney, NSW: UNSW Press, 139-156.

Altman, JC 2007, 'The Howard government's Northern Territory intervention: are neopaternalism and Indigenous development compatible?', presented at the Australian Institute of Aboriginal and Torres Strait Islander Studies Conference, 7 November ,

http://caepr.cass.anu.edu.au/sites/default/files/docs/Altman_AIATSIS_0.pdf [accessed 20 April 2018 ].

Anderson, K and Smith, SJ 2001, 'Editorial: emotional geographies', Transactions Institute of British Geographers, 26, 7-10. 
Andrews, K 2005, Welfare to work - \$3.6 Billion to help people into work: Budget 2005, media release, 10 May, Canberra.

Andrews, $\mathrm{K}$ and Patterson, K 2005, OECD conference confirms Australia continues to lead the way, media release, 4 April, https://formerministers.dss.gov.au/6627/oecd_conference_4arp05/ [accessed 21 March 2018 ].

Anthony, L 2000, \$16 million disability employment trial, media release, 31 August, https://formerministers.dss.gov.au/6989/16-million-disability-employment-trial/ [accessed 21 March 2018 ].

Anthony, L 2001a, Better assessment under Australians working together, media release, 22 May, Canberra, ACT: Australian Government.

Anthony, L 2001b, Reviews up 32\% as Queenslanders dob in welfare cheats, media release, 8 July, https://formerministers.dss.gov.au/7313/reviews_up_32/ [accessed 21 March 2018 ].

APA (Australian Parent Advocacy Inc.) 2003, How will people with disabilities be protected as business services adjust to the reforms? A response from families, Bundaberg: APA.

APA 2004, Sheltered workshop reform package response, Bundaberg: APA.

APA 2005, Submission to the AIRC on Safety-Net hearings for people with a disability employed in Australia's business services, Bundaberg: APA.

Applebaum, L 2001, 'The influence of perceived deservingness on policy decisions regarding aid to the poor', Political Psychology, 22 (3), 419-442.

Archer, M 1998, 'Realism in the social sciences', in M Archer, R Bhaskar, A Collier , T Lawson and A Norrie (eds), Critical realism: essential readings, London: Routledge, 189-206.

Archer, M 2000, Being human: the problem of agency, Cambridge: Cambridge University Press. Australian Fair Work Commission 2016, AFPC employees with disability in Australian disability enterprises decisions, Canberra, ACT: Australian Government, 29 February, www.fwc.gov.au/awards-agreements/minimum-wages-conditions/annual-wagereviews/previous-wage-reviews/afpc-airc [accessed 22 March 2018 ].

Australian Government 2000, The government's statement on welfare reform, Canberra, ACT: Commonwealth of Australia.

Australian Government 2001, Australians working together - helping people to move forward, Fact Sheet 18 - A better deal for people with disabilities - early intervention, better assessment and improved employment assistance services, Canberra, ACT: Commonwealth of Australia. Australian Government 2002, 2002-2003 budget overview, Canberra, ACT: Commonwealth of Australia.

Australian Government 2003, Budget paper no. 2, Canberra, ACT: Commonwealth of Australia. Australian Government 2012, Submission to the Senate inquiry on the adequacy of the allowance payment system for job seekers and others, Canberra, ACT: Australian Government, www.aph.gov.au/Parliamentary_Business/Committees/Senate/Education_Employment_and_W orkplace_Relations/Completed_inquiries/2010-13/newstartallowance/sub̄̄missions [accēssē 22 March $20 \overline{17}$ ].

Australian Government 2017, Closing the gap prime minister's report 2017, Canberra, ACT: Commonwealth of Australia.

Baker, B 2002, 'The hunt for disability: the new eugenics and the normalisation of school children', Teachers College Record, 104, 663-703.

Balakrishnan, R , Heintz, J and Elson, D 2016, Rethinking economic policy for social justice: the radical potential of human rights, London: Routledge.

Barbalet, J 1998, Emotion, social theory, and social structure: a macrosociological approach, Cambridge: Cambridge University Press.

Barnes, C 1997, 'A legacy of oppression: a history of disability in western culture', in L Barton and M Oliver (eds), Disability studies: past, present and future, Leeds: The Disability Press, Chapter 1.

Barnes, C 1999, 'A working social model? Disability, work and disability politics in the 21st century', Critical Social Policy, 20, 441-457.

Barnes, C and Mercer, G 2003, Disability, Cambridge: Polity Press.

Barnes, C and Mercer, G 2005, 'Disability, work and welfare: challenging the social exclusion of disabled people', Work, Employment and Society, 19, 527-545.

Barta T 1987, 'Relations of genocide: land and lives in the colonization of Australia', in I Wallimann and MN Dobkowski (eds), Genocide and the modern age: etiology and case studies of mass death, Westport, CT: Greenwood Press, 237-251. 
Bashford, A 2004, Imperial hygiene: a critical history of colonialism, nationalism and public health, New York, NY: Palgrave Macmillan.

Bauman, Z 1998, 'Time and class', Arena, 10, 69-83.

Bauman, Z 2000, 'Time and space reunited', Time \& Society, 9, 171-185.

Beer, A 2012, 'The economic geography of Australia and its analysis: from industrial to postindustrial regions', Geographical Research, 50, 269-281.

Benn Michaels, W 2006, The trouble with diversity: how we have to love identity and ignore inequality, New York, NY: Metropolitan Books.

Benoit, O 2007, 'Ressentiment and the Gairy social revolution', Small Axe: A Caribbean Journal of Criticism, 22, 95-111.

Ben-Ze'ev, A 2000, The subtlety of emotions, Cambridge, MA: Massachusetts Institute of Technology.

Berns, S 2002, 'Returning to our roots: Australia's new deserving poor', The Australian Feminist Law Journal, 16, 24-52.

Bernstein, M 2005, 'Identity politics', Annual Review of Sociology, 31, 47-74.

Bessant, J 2000 'Civil conscription or reciprocal obligation: the ethics of "work-for-the-dole"', Australian Journal of Social Issues, 35 (1), 15-33.

Bessant, J , Watts, R , Dalton, T and Smyth, P 2006, Talking policy: how social policy is made, Sydney, NSW: Allen \& Unwin.

Bhaskar, R 1993, Dialectic: the pulse of freedom, London: Verso.

Bielefeld, S 2016a, 'Neoliberalism and the return of the guardian state: micromanaging Indigenous peoples in a new chapter of colonial governance', in W Sanders (ed), Engaging Indigenous economy: debating diverse approaches, Canberra, ACT: ANU Press, 155-169. Bielefeld, S 2016b, 'Income management and indigenous women - a new chapter of patriarchal colonial governance?', University of New South Wales Law Journal, 29 (2), 843-878.

Billings, P 2010, 'Social welfare experiments in Australia: more trials for Aboriginal families?', Journal of Social Security Law, 17 (3), 164-197.

Bills Digest 2002, No. 157: Family and Community Services Legislation Amendment (Disability Reform) Bill 2002, Canberra, ACT: Department of the Parliamentary Library, www.aph.gov.au/binaries/library/pubs/bd/2001-02/02bd157.pdf [accessed 22 March 2018 ]. Bills Digest 2003, No. 125: Family and Community Services Legislation Amendment (Disability Reform) Bill (No.2) 2002, Canberra, ACT: Department of the Parliamentary Library, www.aph.gov.au/binaries/library/pubs/bd/2002-03/03bd125.pdf [accessed 22 March 2018 ]. Bills Digest 2005, No. 70: Employment and Workplace Relations Legislation Amendment (Welfare to Work and Other Measures) Bill 2005, Canberra, ACT: Department of the Parliamentary Library.

Bondi, L, Davidson, J and Smith, M 2005, 'Introduction', in J Davidson , L Bondi and M Smith (eds), Emotional geographies, Aldershot: Ashgate, 1-16.

Bourdieu, P 1986, 'The forms of capital', in JG Rochardson (ed), Handbook of theory and research for the sociology of emotion, London: Greenwood Press, 241-258.

Bourdieu, P 1996, 'Understanding', Theory, Culture \& Society, 13, 17-37.

Burawoy, M 2003, 'For a sociological Marxism: the complementary convergence of Antonio Gramsci and Karl Polanyi', Politics \& Society, 31, 193-261.

Burawoy, M 2005, 'Third-wave sociology and the end of pure science', American Sociologist, 36 (3-4), 152-165.

Butler, J 1993, Bodies that matter: on the discursive limits of sex, London: Routledge.

Butler, J 1999, Gender trouble: feminism and the subversion of identity, London: Routledge.

Butler, R and Parr, H (eds) 1999, Mind and body spaces: geographies of illness, impairment and disability, London: Routledge.

Campbell, F 2008, 'Exploring internalised ableism using critical race theory', Disability \& Society, 23 (2), 151-162.

Carney, T 2003, 'Disability and social security: compatible or not?', Australian Journal of Human Rights, 9 (2), 139-172.

Carney, T 2006, 'Neoliberal welfare reform and "rights" compliance under Australian social security law', Australian Journal of Human Rights, 12 (1), 223-253.

Carney, T and Ramia, G 2002, 'Mutuality, Mead \& McClure: more "big M's" for the unemployed', Australian Journal of Social Issues, 37 (3), 277-300. 
Carney, T, Ramia, G and Chapman, A 2007, 'Comparativism, the labour social policy nexus and intra-national analysis: a case study', Policy \& Politics, 35 (2), 233-250.

Cass, B 2005, 'From meeting needs and establishing entitlements to enforcing obligations: 1967-2004', Australian Journal of Social Issues, 40 (1), 33-54.

Cass, B and Brennan, D 2002, 'Communities of support or communities of surveillance and enforcement in welfare reform debates', Australian Journal of Social Issues, 37 (3), 247-262.

Castles, F 2001, 'Farewell to Australia's welfare state', Eureka Street, 11 (1), 13-16.

Chapman, R , Tonts, M and Plummer, P 2014, 'Resource development, local adjustment and regional policy: resolving the problem of rapid growth in the Pilbara, WA', Journal of Rural and Community Development, 9, 72-86.

Charlton, J 1998, Nothing about us without us: disability oppression and empowerment, Berkeley, CA: University of California Press.

Chodorow, N 1978, The reproduction of mothering, Berkeley, CA: University of California Press. Clear, M (ed) 2000, Promises, promises: disability and the terms of inclusion, Sydney, NSW: Federation Press.

Clear, M and Gleeson, B 2001, 'Disability and materialist embodiment', Journal of Australian Political Economy, 49 (1), 34-55.

Coates, $\mathrm{K}$ and Morrison, WR 2005. 'Reconciliation in Northern British Columbia? Future prospects for Aboriginal-newcomer relations', The Northern Review, 25/26 (Summer), 17-34. Cohen, J 1983, 'Rethinking social movements', Berkley Journal of Sociology, 28, 97-113. Cohen, S 2002, Folk devils and moral panics: the creation of the mods and rockers, London: Routledge.

Cohen, S and Taylor, L 1992, Escape attempts: the theory and practice of resistance to everyday life, London: Routledge.

Collyer, F 2003, 'Theorising privatisation: policy, network analysis and class', Electronic Journal of Sociology, 7, 1-21, www.sociology.org.content/vol7.3/01_collyer.html [accessed 25 March 2005 ].

Committee on the Rights of Persons with Disabilities 2017, Concluding observations on the initial report of the United Kingdom of Great Britain and Northern Ireland, CRPD/C/GBR/CO/1, New York, NY: United Nations.

Community Affairs Legislation Committee 2001, Disability Services Amendment (Improved Quality Assurance) Bill 2001, Canberra, ACT: Commonwealth of Australia, 25 September. Community Affairs Legislation Committee 2004, Budget estimates, Canberra, ACT: Commonwealth of Australia, 1 June.

Conley, M 1982, 'The "undeserving poor": welfare and labour policy', in R Kennedy (ed), Australian welfare history: critical essays, Sydney, NSW: Macmillan, 281-303.

Conley, T 2001, 'The domestic politics of globalisation', Australian Journal of Political Science, 36 (2), 223-246.

Connell, R 2008, 'A thousand miles from kind: men, masculinities and modern institutions', The Journal of Men's Studies, 16 (3), 237-252.

Considine, M 2001, Enterprising states: the public management of welfare-to-work, Cambridge: Cambridge University Press.

Cook, J , Roche, M , Williams, C and Windebank, J 2001, 'The evolution of active welfare policies as a solution to social exclusion in Britain', Journal of European Area Studies, 9 (1), 13-26.

Cooper, M 1999, 'The Australian disability rights movement lives', Disability \& Society, 14 (2), 217-226.

Corker, M 1999, 'Differences, conflations and foundations: the limits to 'accurate' theoretical representation of disabled people's experience?', Disability \& Society, 14 (5), 627-642.

Costello, P 2005, 2005-06 budget press release, media release, 10 May, Canberra, ACT: Australian Government.

Crow, L 1996, 'Including all of our lives: renewing the social model of disability', in J Morris (ed), Encounters with strangers: feminism and disability, London: The Women's Press, 206-226.

Cutcher, L and Milroy, T 2010, 'Mispresenting Indigenous mothers: maternity allowance and the media', in S Goodwin and K Huppatz (eds), The good mother: contemporary motherhoods in Australia, Sydney, NSW: University of Sydney Press, 153-174.

Dalton, T , Draper, M , Weeks, W and Wiseman, J 1996, Making social policy in Australia: an introduction, Sydney, NSW: Allen \& Unwin. 
Danermark, B and Coniavitis Gellerstedt, L 2004, 'Social justice: redistribution and recognition a non-reductionist perspective on disability', Disability \& Society, 19 (4), 339-353.

Daniels, D 2006, Social security payments for the aged, people with disabilities and carers 1909 to 2010 - part 1, Social Policy Group, Canberra, ACT: Parliamentary Library of Australia,

www.aph.gov.au/About_Parliament/Parliamentary_Departments/Parliamentary_Library/Publicati ons_Archive/online/Aged1 [accessed 22 March 2018].

Davis, L 1995, Enforcing normalcy: disability, deafness and the body, London: Verso.

Davis, L (ed) 2006, The disability studies reader, 2nd edn, London: Routledge.

Department of Prime Minister and Cabinet 2014, Aboriginal and Torres Strait Islander health performance framework 2014 report: employment, Canberra, ACT: Australian Government, http://www.pmc.gov.au/sites/default/files/publications/indigenous/Health-Performance-

Framework-2014/index.html [accessed 20 April 2018].

DEWR (Department of Employment and Workplace Relations) 2004, Job network disability support pension pilot: interim evaluation report, Canberra, ACT: Australian Government Publishing Services.

DEWR 2005a, Report on the next steps for disability open employment services consultations, Canberra, ACT: Australian Government Publishing Services.

DEWR 2005b, Australians working together: report, Canberra, ACT: Australian Government Publishing Services.

DeSouza, R and Cormack, D 2009, 'Returning the Indigenous to the centre: a view from Aotearoa/New Zealand', Diversity in Health and Care 6, 219-221.

Disability Bitch 2010, Blame it on disability bitch. Ouch! 23 June, London: BBC, www.bbc.co.uk/ouch/opinion/b1tch/db_emergency_budget_2010.shtml [accessed 21 August 2010 ].

DEAC and NCID (Disability Employment Action Centre and National Council on Intellectual Disability) 2003, Safety net review 2003: written submission, Melbourne, VIC: DEAC.

DPA (Disability Participation Alliance) 2005a, Briefing on the 2002 Disability Reform Bill, Sydney, NSW: DPA.

DPA 2005b, Background paper, people with disability: participation and payment forum, Sydney, NSW: DPA.

DPA 2005c, Response to the 2005/2006 federal budget 'welfare to work' package, Sydney, NSW: DPA.

Donati, P 1984, 'Organisation between movement and institution', Social Science Information, 23 (4-5), 837-859.

Dowse, L 2007, Stand up and give 'em the fright of their life, thesis (PhD), University of New South Wales.

DSS (Department of Social Services) 2013, Characteristics of disability support pension recipients, Canberra, ACT: Australian Government.

DSS 2015, Department of Human Services administrative data (DSS extracts) at 26 June 2015, Canberra, ACT: Australian Government, http://data.gov.au/dataset/4ccff587-4a46-4ab9-883376dadaa10ebe/resource/c42f7b34-15a0-4516-ba96-91ea5290540d/download/disabilitysupport-pension-payment-trends-and-profile-report.pdf [accessed 26 June 2017 ].

DSS 2017, DSS demographics March 2017, Canberra, ACT: Australian Government, https://data.gov.au/dataset/dss-payment-demographic-data/resource/adbe8196-5669-4f33b01a-65b04ad41b55?view_id=f71bd20c-1a49-444d-b778-b5105b0c5261 [accessed 20 April 2018 ].

Edwards, C 2014, 'Emplacing disabled bodies/minds in criminal law: regulating sex and sexual consent in Ireland's Criminal Law (Sexual Offences) Act 1993', in K Soldatic , H Morgan and A Roulstone (eds), Disability, spaces and places of policy exclusion, London: Routledge, 31-47. Edwards, C and Imrie, R 2003, 'Disability and bodies as bearers of value', Sociology, 37, 239-256.

Edwards, J 2006, 'Conceptualising hy-bivalent subjectivities to facilitate an examination of Australian government mutual obligations policies', Journal of Education Policy, 21 (4), 417-436.

Ellinghaus, K 2003, 'Absorbing the "Aboriginal problem": controlling interracial marriage in Australia in the late 19th and early 20th centuries', Aboriginal History 27, 183-207. FaCS (Department of Family and Community Services) 1999, Commonwealth disability services census 1998, Canberra, ACT: Australian Government Publishing Services. 
FaCS 2000, Commonwealth disability services census 1999, Canberra, ACT: Australian Government Publishing Services.

FaCS 2002a, Implementing case based funding for disability employment assistance: evaluation findings and options for final funding arrangements consultation paper, Canberra, ACT: Australian Government Publishing Services.

FaCS 2002b, Commonwealth disability services census 2000, Canberra, ACT: Australian Government.

FaCS 2003a, Commonwealth disability services census 2001, Canberra, ACT: Australian Government.

FaCS 2003b, Disability employment assistance program procedures - case based funding, 2003-2004, version 1 May 2003, Canberra, ACT: Australian Government.

FaCS 2004, Australian Government disability services census 2002, Canberra, ACT: Australian Government.

FaCS 2005a, Australian Government disability services census 2003, Canberra, ACT:

Australian Government.

FaCS 2005b, Australian Government disability services census 2004, Canberra, ACT:

Australian Government.

Feather, N 1999, 'Judgements of deservingness: studies in the psychology of justice and achievement', Personality and Social Psychology Review, 3 (2), 86-107.

Feather, N 2006, 'Deservingness and emotions: applying the structural model of deservingness to the analysis of affective reactions to outcomes', European Review of Social Psychology, 17 (1), 38-73.

Feather, N and Nairn, K 2005, 'Resentment, envy, schadenfreude, and sympathy: effects of own and other's deserved or undeserved status', Australian Journal of Psychology, 57 (2), 87-102.

Fine, M and Asch, A (eds) 1988, Women with disabilities: essays in psychology, culture and politics, Philadelphia, PA: Temple University Press.

Finkelstein, V 1980, Attitudes and disabled people: issues for discussion, New York, NY: World Rehabilitation Fund.

Finkelstein, V 2001, The social model repossessed, The Disability Studies Archive UK, Centre for Disability Studies, University of Leeds, www.leeds.ac.uk/disability-

studies/archiveuk/archframe.htm [accessed 13 September 2004 ].

Finn, D 2000, 'From full employment to employability: a new deal for Britain's unemployed', International Journal of Manpower, 21 (5), 384-395.

Finn, D 2002, 'Getting welfare to work: lessons from Britain's "new deal"', Australian Journal of Labour Economics, 5 (4), 471-487.

Finnegan, R 2006, 'Using documents', in R Sapsford and V Jupp (eds), Data collection and analysis, 2nd edn, London: Sage Publications, 138-153.

First Nations National Constitutional Convention 2017, Uluru statement of the heart, www.referendumcouncil.org.au/sites/default/files/2017-

05/Uluru_Statement_From_The_Heart.PDF [accessed 20 April 2018 ].

Fiske, $L$ and Briskman, $L$ 2007, 'Rights and responsibilities: reclaiming human rights in political discourse', Just Policy, 43, 50-54.

Foucault M 1970, The order of things: an archaeology of the human sciences, London:

Routledge.

Foucault M 1973, The birth of the clinic: an archaeology of medical perception, London:

Routledge.

Foucault, M 1977, Discipline and punish, London: Penguin.

Foucault, M 1989, Madness and civilisation, London: Routledge.

Fox, C 2000, Fighting back: the politics of the unemployed in Victoria in the great depression, Melbourne, VIC: Melbourne University Press.

Fraser, N 1995, 'From redistribution to recognition? Dilemmas of justice in a post-socialist age', New Left Review, 2, 68-93.

Fraser, N 2007, 'Feminist politics in the age of recognition: a two-dimensional approach to gender justice', Studies in Social Justice, 1 (1), 23-35.

Fraser, N 2013, Fortunes of feminism: from state-managed capitalism to neoliberal crisis, London: Verso. 
French, S and Swain, J 2008, 'Service user involvement', in R Jones and F Jenkin (eds), Management, leadership and development in the allied health professionals: an introduction, Abingdon: Radcliffe Publications.

Frohmader, C, Meekosha, H and Soldatic, K 2014, 'Unruly mothers or unruly practices? Disabled mothers surviving oppressive state practices in Australia', in G Filax and D Taylor (eds), Disabled mothers: stories and scholarship by and about mothers with disabilities, Bradford, ON: Demeter Press, 295-313.

Galvin, R 2002, 'Disturbing notions of chronic illness and individual responsibility: towards a genealogy of morals', Health: interdisciplinary journal for the social study of health, illness and medicine, 6 (2), 107-137.

Galvin, R 2004a, 'Can welfare reform make disability disappear?', Australian Journal of Social Issues, 39 (3), 343-353.

Galvin, R 2004b, Liberating the disabled identity: a coalition of subjugated knowledges, thesis (PhD), Murdoch University.

Galvin, R 2006, 'A genealogy of the disabled identity in relation to work and sexuality', Disability \& Society, 21 (5), 499-512.

Garland-Thomson, R (ed) 1996, Freakery: cultural spectacles of the extraordinary body, New York, NY: New York University Press.

Garland-Thomson, R 1997, Extraordinary bodies: figuring physical disability in American culture and literature, New York, NY: Columbia University Press.

Garon, J 2004, 'Skeletons in the closet', International Forum of Psychoanalysis, 13 (1-2), 84-92.

Ghai, A 2003, (Dis)embodied form: issues of disabled women, New Delhi: Har-Anand Publications.

Gilroy J and Donelly M 2016, 'Australian Indigenous people with disability: ethics and standpoint theory', in S Grech and K Soldatic (eds), Disability in the global south: the critical handbook, New York, NY: Springer, Chapter 35.

Gilroy, J and Emerson, E 2016, 'Australian Indigenous children with low cognitive ability: family and cultural participation', Research in Developmental Disabilities, 56, 117-127.

Gilroy, J , Dew, A , Lincoln, M and Hines, M 2016, 'Need for an Australian Indigenous disability workforce strategy: review of the literature', Disability and Rehabilitation, 1-10, doi:10.1080/09638288.2016.1201151.

Gleeson, B 1997, 'Disability studies: a historical materialist view', Disability \& Society, 12, 179-202.

Gleeson, B 1998, 'Disability and poverty', in R Fincher and J Nieuwenhuysen (eds), Australian poverty: then and now, Melbourne, VIC: Melbourne University Press, 314-333.

Gleeson, B 1999, Geographies of disability, London: Routledge.

Glennie, P and Thrift, N 1996, 'Reworking E. P. Thompson's "Time, work-discipline and industrial capitalism"', Time and Society, 5 (3), 275-299.

Goffman, E 1963, Stigma: notes on the management of spoiled identity, Englewood Cliffs: Prentice Hall.

Goggin, G and Newell, C 2000, 'An end to disabling policies? Toward enlightened universal service', The Information Society, 16 (2), 127-133.

Goggin, G and Newell , C 2005, Disability in Australia: exposing a social apartheid, Sydney, NSW: University of New South Wales.

Goode, E and Ben-Yehuda , N 1994, Moral panics: the social construction of deviance, Cambridge: Blackwell Publishing.

Goodin, R 2002, 'Structures of mutual obligation', Journal of Social Policy, 31 (4), 579-596. Goodin, R , Headey, B , Muffels, R and Driven, H 1999, The real worlds of welfare capitalism, Cambridge: Cambridge University Press.

Gothard, J 1998, 'Burden on the state: the "unfit" immigrant', in E Richards and J Templeton (eds), The Australian immigrant in the 20th century: searching neglected sources, Canberra, ACT: Australian National University, 38-64.

Gordon, S 2017, 'Indigenous recognition: Turnbull government's rejection of Uluru statement from the heart indefensible', ABC, 27 October, www.abc.net.au/news/2017-10-27/decision-toreject-uluru-statement-is-indefensible/9093408 [accessed 20 April 2018 ].

Grant, E , Zillante, G , Tually, S , Chong, A, Srivastava, A, Lester, A, Beilby, J and Beer, A 2016, Housing and Indigenous people living with a disability: lived experiences of housing and 
community infrastructure, Adelaide, SA: Australian Institute of Housing Research.

Greenfield, C and Williams, P 2003, 'Limiting politics: Howardism, media rhetoric and the national cultural commemorations', Australian Journal of Political Science, 38 (2), 279-297. Greensmith, C 2012, 'Pathologizing Indigeneity in the Caledonia "crisis"', Canadian Journal of Disability Studies 1 (2), 19-42.

Grieves, V 2008, 'The "battlefields": identity, authenticity and Aboriginal knowledges in Australia', in H Minde (ed), Indigenous peoples: self-determination, knowledge, Indigeneity, Delft, Netherlands: Eburon Academic Publishers, 287-312.

Grosz, E 2005, Time travels: feminism, nature, power, Sydney, NSW: Allen \& Unwin. Grover, C and Piggott, L 2005, 'Disabled people, the reserve army of labour and welfare reform', Disability \& Society, 20 (7), 705-717.

Grover, C and Piggott, L 2010, 'Disgusting! Understanding financial support for disabled people in the UK', presented at Disability Studies 5th biannual.

Habibis, D 2013, 'Australian housing policy, misrecognition and Indigenous population mobility', Housing Studies, 28 (5), 764-781.

Hacking, I 1991, 'How should we do a history of statistics?', in G Burchell , C Gordon and P Miller (eds), The Foucault effect: studies in governmental nationality, London: Harvester Wheatsheaf, 181-196.

Hamilton, C and Maddison, S (eds) 2007, Silencing dissent, Sydney, NSW: Allen \& Unwin. Hancock, A 2004, The politics of disgust: the public identity of the welfare queen, New York, NY: New York University Press.

Harris, P 2001, 'From relief to mutual obligation: welfare rationalities and unemployment in 20thcentury Australia', Journal of Sociology, 37, 5-26.

Harris, P 2002, 'Welfare rewritten: change and interplay in social and economic accounts', Journal of Social Policy, 31, 377-398.

Hart, V 2003, 'Teaching black and teaching back', Social Alternatives 22 (3), 12-15.

Harvey, D 1989, The condition of postmodernity, Cambridge: Blackwell Publishing.

Harvey, D 2005, A brief history of neoliberalism, Oxford: Oxford University Press.

Hawkesworth, M 2001, 'Disabling spatialities and the regulation of the visible secret', Urban Studies, 38 (2), 299-318.

Hayek, F 1960, The constitution of liberty, London: Routledge.

Haylett, C 2003, 'Remaking labour imaginaries: social reproduction and the internationalising project of welfare reform', Political Geography, 22, 765-788.

Hetherington, K 2001, 'Moderns as ancients: time, space and the discourse of improvement', in J May and N Thrift (eds), Timespace: geographies of temporality, London: Routledge.

Hevey, D 1992, The creatures time forgot, London: Routledge.

Hill Collins, $\mathrm{P}$ and Bilge, S 2016, Intersectionality, London: Wiley.

Hobsbawm, E 1987, The age of empire, London: Abacus Books.

Hollinsworth, D 2013, 'Decolonizing Indigenous disability in Australia', Disability \& Society, 28, 601-615.

Hope, W 2006, 'Global capitalism and the critique of real time', Time \& Society, 15 (2/3), 275-302.

House of Representatives Hansard 2002, Official Hansard, Canberra, ACT: Commonwealth of Australia, 16 May.

House of Representatives Hansard 2005, Official Hansard, Canberra, ACT: Commonwealth of Australia, 9 November.

Howard, J 2004, \$99 million safety net for disability, media release, 21 April, Canberra, ACT: Australian Government.

Howard, J and Newman, J 2000, Welfare reform: a stronger, fairer Australia, Canberra, ACT: Australian Government.

Howard-Hassman, R 2004, 'Culture, human rights, and the politics of resentment in the era of globalisation', Human Rights Review, 1, 5-26.

Howard-Wagner, D 2017, 'Governance of Indigenous policy in the neo-liberal age: Indigenous disadvantage and the intersecting of paternalism and neo-liberalism as a racial project', Race and Ethnic Studies, 41 (7), 1332-1351.

Howitt, R and McLean, J 2015, 'Towards closure? Coexistence, remoteness and righteousness in Indigenous policy in Australia', Australian Geographer, 46 (2), 137-145, 
doi:10.1080/00049182.2015.1020992.

Hughes, B 2015, 'Disabled people as counterfeit citizens: the politics of resentment past and present', Disability \& Society, 30 (7), 991-1004.

Hughes, B 2017, 'Impairment on the move: the disabled incomer and other invalidating intersections', Disability \& Society, 32 (4), 1-16.

Humpage, L 2007, 'Models of disability, work and welfare in Australia', Social Policy \& Administration, 41 (3), 215-231.

Hunter, E 1993, Aboriginal health and history: power and prejudice in remote Australia, Cambridge: Cambridge University Press.

Hyde, M 1994, 'Woman bettering as a martial act: interviewing and analysis of context', in C Riessman (ed), Qualitative studies in social work research, London: Sage, 95-112.

Imrie, R 2001, 'Barriered and bounded places and the spatialities of disability', Urban Studies, 38, 231-237.

Imrie, R 2014, 'Space, place and policy regimes: the changing contours of disability and citizenship', in K Soldatic , H Morgan and A Roulstone (eds), Disability, spaces and places of policy exclusion, London: Routledge, 13-30.

Jacob, MD 2009, White mother to a dark race: settler colonialism, maternalism, and the removal of Indigenous children in the American west and Australia, 1880-1940, Lincoln: University of Nebraska Press.

Jakubowicz, A and Meekosha, H 2002, 'Bodies in motion: critical issues between disability studies and multicultural studies', Journal of Intercultural Studies, 23, 237-252.

Jakubowicz, A and Meekosha H 2003, 'Can multiculturalism encompass disability?', in S Riddell and N Watson (eds), Disability, culture and identity, Harlow: Pearson Education, 180-199.

Jarman, M , Lamp, S , Mitchell, D , Nepveux, D , Nowell, N and Snyder, S 2002, 'Theorising disability as political subjectivity: work by the UIC Disability Collective on political subjectivities', Disability \& Society, 17, 555-569.

Jayasuriya, K 2002, 'The new contractualism: neo-liberal or democratic?', Political Quarterly, 73 (3), 309-319.

Jessop, B 2002, The future of the capitalist state, Cambridge: Polity Press.

Jessop, B 2008, State power, Cambridge: Polity Press.

Johnson, N 2001, 'From time immemorial: narratives of nationhood and the making of national space', in J May and N Thrift (eds), Timespace: geographies of temporality, London: Routledge, 89-105.

Johnson, J , Cant, G , Howitt, R and Peters, E 2007, 'Creating anti-colonial geographies: embracing Indigenous peoples' knowledge and rights', Geographical Research, 45, 117-120. Jordan, JD 2018, 'Evidence from the "frontline"? An ethnographic problematisation of welfareto-work administrator opinions', Work, Employment and Society, 32 (1), 57-74.

Jupp, V 2006, 'Documents and critical research', in R Sapsford and V Jupp (eds), Data collection and analysis, 2nd edn, London: Sage Publications, 270-300.

Keane, J 2004, Violence and democracy, Cambridge: Cambridge University Press.

Kemp, D 2001, Australians working together - \$119 million for training and education, media release, 22 May, Canberra, ACT: Australian Government.

Kitchin, RM and Law, R , 2001, 'The socio-spatial construction of disabled access toilets', Urban Studies, 32, 287-298.

Knaus, C 2017, 'Disability advocacy groups warn funding withdrawal may force them to close', The Guardian, 27 November, www.theguardian.com/australia-news/2017/nov/27/disabilityadvocacy-groups-warn-funding-withdrawl-may-force-them-to-close [accessed 27 March 2018 ]. KPMG 2000, A viable future: strategic imperatives for business services, Canberra, ACT: Commonwealth of Australia.

Kurzer, P 2001, Markets and moral regulation, Cambridge: Cambridge University Press. Ladd-Taylor, M and Umansky, L 1998, 'Bad mothers': the politics of blame in twentieth-century America, New York, NY: New York University Press.

Lake, M 1992, 'The politics of respectability', in G Whitlock and D Carter (eds), Images of Australia, Brisbane, QLD: University of Queensland Press, 75-131.

Lappalainen, S 2009, 'Making differences and reflecting on diversities: embodies nationality among preschool children', International Journal of Inclusive Education, 13 (1), 63-78. Lawson, J 2001, 'Disability as a cultural identity', International Studies in Sociology of Education, 11 (3), 203-222. 
Levitas, R 1998, The inclusive society? Social exclusion and new labour, London: Macmillan. Lister, R 2001, 'Towards a citizens' welfare state: the $3+2$ "R"s of welfare reform', Theory, Culture \& Society, 18, 91-111.

Macali, L 2006, 'Contemporary disability employment policy in Australia: how can it best support transitions from welfare to work?', Australian Bulletin of Labour, 32 (3), 227-239.

McClelland, A 2006, 'What is social policy?', in A McClelland and P Smyth (eds), Social policy in Australia: understanding for action, Melbourne, VIC: Oxford University Press, 5-20.

McClintock, A 2000, Double crossings: madness, sexuality and imperialism, The 2000 Garnett Sedgewick Memorial Lecture, Vancouver: Ronsdale Press.

Mclnnes, E 2007, Welfare to work: creating a new social security exclusion system, Perth, WA: Institute of Advanced Studies.

Macklin, J 2008, Letter to women with disabilities Australia, 4 April, Canberra, ACT:

Commonwealth of Australia.

Macklin, J 2011, 'Tackling disadvantage in the midst of the boom', ministerial keynote speech at Economic and Social Outlook Conference, Melbourne, 30 June .

McRuer, R 2012, 'Cripping queer politics, or the dangers of neoliberalism', The Scholar \&

Feminist Online, 10 (1-2), http://sfonline.barnard.edu/a-new-queer-agenda/cripping-queer-

politics-or-the-dangers-of-neoliberalism/ [accessed 13 November 2017 ].

McRuer, R 2018, Crip times: disability, globalisation and resistance, New York, NY: New York University Press.

Maddison, S 2007, 'Redefining democracy', in C Hamilton and S Maddison (eds), Silencing dissent, Sydney, NSW: Allen \& Unwin, 24-40.

Maddison, S 2008, 'Indigenous autonomy matters: what's wrong with the Australian government's "intervention" in Aboriginal communities', Australian Journal of Human Rights, 14 (1), 40-61.

Maddison, S and Hamilton, C 2007, 'Non-government organisations', in C Hamilton and S Maddison (eds), Silencing dissent, Sydney, NSW: Allen \& Unwin, 78-100.

Maddison, S and Martin, G 2009, Surviving neoliberalism: the persistence of Australian social movements, Minneapolis, MN: University of Minnesota Press.

Maddison, S and Martin, G 2010, 'Surviving neoliberalism: the persistence of social movements', Social Movement Studies, 9 (2), 101-120.

Maddison, S and Scalmer, S (eds) 2006, Activist wisdom: practical knowledge and creative tensions in social movements, Sydney, NSW: University of New South Wales Press.

Malhotra, R 2006, 'Justice as fairness in accommodating workers with disabilities and critical theory: the limitations of a Rawlsian framework for empowering people with disabilities in Canada', in D Pothier and R Devlin (eds), Critical disability theory, Vancouver: University of British Columbia Press.

Marks, D 1999, 'Dimensions of oppression: theorising the embodied subject', Disability \& Society, 14 (5), 611-626.

Marston, G , Cowling, S and Bielefeld, S 2016, 'Tensions and contradictions in Australian social policy reform: compulsory income management and the National Disability Insurance Scheme', Australian Journal of Social Issues, 51 (4), 399-417.

Martin, S 2007, Welfare reform, the underclass thesis and the process of legitimising social divisions, Melbourne, VIC: The Australian Centre, University of Melbourne.

Martin, KL 2008, Please knock before you enter: Aboriginal regulation of outsiders and the implications for researchers, Brisbane, QLD: Post Pressed.

Massey, D 1994, Space, place and gender, Minneapolis, MN: University of Minnesota Press. May, J and Thrift, N 2001, Timespace: geographies of temporality, London: Routledge.

Mead, L 1986, Beyond social entitlement: the social obligation of citizenship, New York, NY: Free Press.

Meekosha, H 1999, 'Disability and human rights', presented at the Attorney General's NGO Forum on Domestic Human Rights, Canberra, 11 March .

Meekosha, H 2001, 'The politics of recognition or the politics of presence: the challenge of disability', in M Sawer and G Zappala (eds), Speaking for the people: representation in Australian politics, Melbourne, VIC: Melbourne University Press, 225-245.

Meekosha, H 2002, 'Virtual activists? Women and the making of identities of disability', Hypatia, 17 (3), 67-88. 
Meekosha, $\mathrm{H}$ 2005, 'A feminist/gendered critique of the intersections of race and disability: the Australian experience', presented at the University of British Columbia, 23 June.

Meekosha, H 2011, 'Decolonising disability: thinking and acting globally', Disability \& Society, 26 (6), 667-682.

Meekosha, H and Dowse, L 1997, 'Enabling citizenship: gender, disability and citizenship in Australia', Feminist Review, 57, 49-72.

Meekosha, $\mathrm{H}$ and Mowbray, M 1990, 'Reconstruction to deconstruction: the transformation of community work in Australia', Community Development Journal, 25 (4), 337-344.

Mendes, P 2008, Australia's welfare wars revisited, 2nd edn, Sydney, NSW: University of New South Wales Press.

MHCC (Mental Health Co-ordinating Council Employment Sub-Committee) 2000, Review of mental health employment issues, Sydney, NSW: MHCC.

Milbourne, P 2010, 'Putting poverty and welfare in place', Policy \& Politics, 38, 153-169.

Miller, F and Alvarado, K 2005, 'Incorporating documents into qualitative nursing research', Journal of Nursing Scholarship, 37 (4), 348-353.

Miller, S 2004, Disgust: the gatekeeper emotion, Hillsdale, NJ: The Analytic Press.

Miller, W 1997, The anatomy of disgust, Cambridge, MA: Harvard University Press.

Mink, G 1998, Welfare's end, Ithaca, NY: Cornell University Press.

Minkoff, D 1999, 'Bending with the wind: strategic change and adaptation by the women's and racial minority organisations', American Journal of Sociology, 104 (6), 1666-1703.

Mitchell, D 1996, 'Sickening bodies: how racism and essentialism feature in Aboriginal women's discourse about health', The Australian Journal of Anthropology, 7 (3), 258-274.

Mitchell, D and Snyder, S 2003, 'The eugenic Atlantic: race, disability, and the making of an international eugenic science, 1800-1945', Disability \& Society, 18 (7), 843-864.

Mitchell, DT and Snyder, SL 2015, The biopolitics of disability: neoliberalism, ablenationalism and peripheral embodiment, Ann Arbor, MI: University of Michigan Press.

Mladenov, T 2009, 'Institutional woes of participation: Bulgarian disabled people's organisations and policy-making', Disability \& Society, 24 (1), 33-45.

Mladenov, T 2017, Disability and Postsocialism, London: Routledge.

Moreton-Robinson, A 2004, 'Whiteness, epistemology and Indigenous representation', in Moreton-Robinson (ed), Whitening race: essays in social and cultural criticism, Canberra, ACT: Australian Studies Press, 75-88.

Moreton-Robinson, AM 2009, 'Imagining the good Indigenous citizen: race war and the pathology of patriarchal white sovereignty', Cultural Studies Review, 15 (2), 61-79.

Morris, A 2006, 'Pain and mythology: disability support pension recipients and work', Australian Review of Public Affairs, 7 (1), 49-59.

Morris, A, Wilson, S and Soldatic, K 2015, 'Hard yakka: disabled people's experience of living on Newstart', in C Grover and L Piggott (eds), Work, welfare and disabled people: UK and international perspectives, Bristol: Policy Press.

Morris, J 1991, Pride against prejudice: transforming attitudes to disability, London: The Women's Press.

Moss, J 2006, "'Mutual obligation" and "new deal": illegitimate and unjustified', Ethical Theory and Moral Practice, 8, 87-104.

Murray, S 2008, Representing autism: culture, narrative, fascination, Liverpool: Liverpool University Press.

NCID (National Council on Intellectual Disability) 2006, The disability services amendment (improved quality assurance) bill 2001: submission to the Community Affairs Legislation Committee, Canberra, ACT: NCID.

Neave, C 2016, Department of Human Services: accessibility of disability support pension for remote Indigenous Australians, Canberra, ACT: Commonwealth Ombudsman.

Neilsen, KE 2008, 'Historical thinking and disability thinking', Disability Studies Quarterly, 28 (3), $1-2$.

Nevile, A 2008, 'Human rights, power and welfare conditionality', Australian Journal of Human Rights, 14 (1), 1-20.

Newell, C 1996, 'The disability rights movement in Australia: a note from the trenches', Disability \& Society, 11 (5), 429-432.

Newman, J 1999a, 'The future of welfare in the 21st century', presented at the National Press Club, Canberra, 29 September, 
http://parlinfo.aph.gov.au/parllnfo/search/display/display.w3p;query=Id\%3A\%22media\%2Fpress rel\%2FNZF06\%22 [accessed 20 March 2018 ].

Newman, J 1999b, Ministerial statement on the national disability advocacy program review: report recommendations, Australian Government, Canberra, 22 July 1999.

Newman, J , 2000, Interview in 7.30 report, ABC, 8 November.

Nietzsche, F 1989, On the genealogy of morals, London: Vintage Books.

Nussbaum, M 2001, Upheavals of thought: the intelligence of emotions, Cambridge: Cambridge University Press.

Nussbaum, M 2004, Hiding from humanity: disgust, shame and the law, Princeton, NJ:

Princeton University Press.

Nussbaum, M 2007, Frontiers of justice: disability, nationality and species membership, Cambridge, MA: Belknap Press of Harvard University Press.

O'Connor, J , Orloff, S and Shaver, S 1999, States, markets, families: gender, liberalism and social policy in Australia, Canada, Great Britain and the United States, Cambridge: Cambridge University Press.

Oliver, M 1986, 'Social policy and disability: some theoretical issues', Disability, Handicap \& Society, 1 (1), 5-17.

Oliver, M 1990, The politics of disablement, London: Macmillan.

Oliver, M 1996, Understanding disability: from theory to practice, London: Macmillan.

Ong, A 2007, Neoliberalism as exception: mutations in citizenship and sovereignty, Durham, NC: Duke University Press.

Parker, S 2007, Searching for the absent citizen: negotiating citizenship, human rights and social justice for people with disabilities in international and domestic legislation and policy, thesis (PhD), Sydney University.

Paterson, K and Hughes, B 1999, 'Disability studies and phenomenology: the carnal politics of everyday life', Disability \& Society, 14 (5), 597-610.

Patterson, K 2003, Welfare reform: is it helping the disadvantaged into jobs and mainstream society?, Economic and Social Policy Outlook Conference - Pursuing Opportunity and Prosperity, Melbourne Institute, Melbourne, 13 November .

https://melbourneinstitute.unimelb.edu.au/outlook/assets/2003/KayPatterson-S.pdf [accessed 27 March 2018 ].

Peck, J 2001, Workfare states, New York, NY: The Guildford Press.

Peck, J 2011, 'Global policy models, globalizing poverty management: international convergence or fast-policy integration?' Geography Compass, 5 (4), 165-181.

Peck, J and Theodore, N 2000, "'Work first": workfare and the regulation of contingent labour markets', Cambridge Journal of Economics, 24, 119-138.

Peck, J and Theodore, N 2015, Fast policy: experimental statecraft at the thresholds of neoliberalism, Minneapolis, MN: University of Minnesota Press.

Peetz, D 2005, Lies, AWAs and statistics, Workers Online,

www.workers.labor.net.au/features/200506/b_tradeunion_awas.html [accessed 30 June 2005 ]. Penovic, T and Dastyari, A 2007, 'Boatloads of incongruity: the evolution of Australia's offshore processing regime', Australian Journal of Human Rights, 13 (1), 33-61.

Peterson, N 2004, 'Myth of the "walkabout": movement in the Aboriginal domain', in J Taylor and M Bell (eds), Population mobility and Indigenous peoples in Australasia and North America, London: Routledge, 223-238.

Pini, B , Brown, K and Previte, J 2004, 'Politics and identity in cyberspace: a case study of Australian women in agriculture online', in W van de Donk, B Loader, PG Nixon, and D Rucht (eds), Cyberprotest: new media, citizens and social movements, London: Routledge, 259-275. Piven, F and Cloward, R 1972 [1956], Regulating the poor: the functions of public welfare, London: Tavistock Publications.

Povinelli, E 2011, 'The governance of the prior', Interventions: International Journal of Postcolonial Studies, 13 (1), 13-30, doi:10.1080/1369801X.2011.545575.

Porter, C 2017, Social services legislation amendment (omnibus savings and child care reform) bill 2017, second reading, 8 February, Canberra, ACT: Parliament of Australia.

Productivity Commission 2003, Report on government services 2003, Canberra, ACT:

Australian Government.

Productivity Commission 2011, Disability care and support: inquiry report, no. 54, Melbourne, VIC: Australian Government. 
Proudfoot, F and Habibis, D 2015, 'Separate worlds: a discourse analysis of mainstream and Aboriginal populist media accounts of the Northern Territory emergency response in 2007', Journal of Sociology, 51 (2), 170-188, doi:10.1177/144078331348236.

Prout, S 2009, 'Security and belonging: reconceptualising Aboriginal spatial mobilities in Yamatji country, Western Australia', Mobilities, 4 (2), 177-202.

Ramia, G 2002, 'The "new contractualism", social protection and the Yeatman thesis', Journal of Sociology, 38, 49-68.

Rapley, M 2001, The social construction of intellectual disability, Cambridge: Cambridge University Press.

Rawls, J 1999, A theory of justice, 2nd edn, Cambridge, MA: Belknap Press of Harvard University Press.

Reference Group on Welfare Reform 2000, Participation for a more equitable society (McClure report), Canberra, ACT: Australian Government.

Riddell, S and Watson, N (eds) 2003, Disability, culture and identity, Essex: Pearson Education. Roden, D , Ellis, K and Lebeck, P 2014, Disability, obesity and ageing, London: Routledge.

Rose, D 2006, 'What if the angel of history were a dog?' Cultural Studies Review, 12 (1), 67-78.

Rose, N 1996, Inventing our selves: psychology, power and personhood, Cambridge:

Cambridge University Press.

Rose, N 1999, Governing the soul: the shaping of the private self, 2nd edn, London: Free Association Books.

Roulstone, A and Barnes, C 2005, Working futures? Disabled people, policy and social inclusion, Bristol: Policy Press.

Roulstone, A and Morgan, $\mathrm{H}$ 2009, 'Neo-liberal individualism or self-directed support: are we all speaking the same language on modernising adult social care?' Social Policy and Society, 8

(3), 333-345.

Roulstone, A and Prideaux, S 2012, Understanding disability policy, Bristol: Policy Press.

Rowse, T 1998, White flour, white power: from rations to citizenship in central Australia,

Cambridge: Cambridge University Press.

Russell, M 1998, Beyond ramps: disability at the end of the social contract, Monroe, ME:

Common Courage Press.

Russell, M 2001, 'Disablement, oppression, and the political economy', Journal of Disability Policy Studies, 12, 87-100.

Sayer, A 1992, Method in social science, 2nd edn, London: Routledge.

Sayer, A 1995, Radical political economy: a critique, Oxford: Blackwell Publishers.

Sayer, A 2000, 'Equality and moral economy', presented at the Equality Studies Centre 10th anniversary conference, Dublin, www.lancaster.ac.uk/fass/resources/sociology-onlinepapers/papers/sayer-equality-and-moral-economy.pdf [accessed 27 March 2018 ].

Sayer, A 2001, 'What are you worth? Recognition, valuation and moral economy', presented at the British Sociological Association Annual Conference, Lancaster University,

www.lancaster.ac.uk/fass/resources/sociology-online-papers/papers/sayer-what-are-youworth.pdf [accessed 27 March 2018 ].

Sayer, A 2003 '(De-)commodification, consumer culture and moral economy', Environment and Planning: Society and Space, 21, 341-357.

Sayer, A 2005, The moral significance of class, Oxford: Oxford University Press.

Scheff, T 1988, 'Shame and conformity: the deference-emotions system', The American Sociological Review, 53 (3), 395-406.

Scheff, T and Retzinger, S 1991, Emotions and violence: shame and rage in destructive conflicts, Massachusetts: Lexington Books.

Schram, S, Fording, R and Soss, J 2008, 'Neo-liberal poverty governance: race, place and the punitive turn in US welfare policy', Cambridge Journal of Regions, Economy and Society, 1 (1), 17-36.

Schwanen, T 2006, 'Arriving "on time", but what is "on time?"', Geoforum, 37 (3), 882-894.

Senate Hansard , 5 September 1991, Minister Howe Ministerial Statement: Social Justice for

People with Disabilities, 788

Senate Hansard 1999a, Senate official Hansard: parliamentary debates, Canberra, ACT:

Commonwealth of Australia, 29 September.

Senate Hansard 1999b, Senate official Hansard: parliamentary debates, Canberra, ACT:

Commonwealth of Australia, 14 October. 
Senate Hansard 2001, Senate official Hansard: parliamentary debates, Canberra, ACT:

Commonwealth of Australia, 23 May.

Senior, K , Hall, J and Daniels, D 2018, 'The capacity to aspire and the Ngukurr news: exploring the economic potential of a community newspaper', Global Media Journal,

http://www.hca.westernsydney.edu.au/gmjau/.

Sennett, R 1994, Flesh and stone: the body and the city in western civilisation, London:

Penguin.

Serr, K (ed) 2017, Thinking about poverty, Sydney, NSW: Federation Press.

Shaver, S 1989, 'Gender, class and the welfare state: the case of income security in Australia', Feminist Review, 32, 90-110.

Shaver, S 2001, 'Australian welfare reform: from citizenship to social engineering', Australian Journal of Social Issues, 36, 277-293.

Shaver, S 2002, 'Australian welfare reform: from citizenship to supervision, Social Policy \& Administration, 36 (4), 331-345.

Sherry, M 2007, '(Post)colonising disability', Wagadu, Special issue: intersecting gender and disability perspectives in rethinking postcolonial identities, 4, 10-22.

http://appweb.cortland.edu/ojs/index.php/Wagadu/article/viewArticle/323/610.

Shilling, C 2003, The body and social theory, 2nd edn, London: Sage.

Shorten, B 2008, $\$ 500,000$ to expand advocacy for people with disability, media release,

Canberra, ACT: Australian Government, 31 October,

https://formerministers.dss.gov.au/4808/expand_advocacy_31oct08/ [accessed on 27 March

2018].

Siebers, T 2002, 'Tender organs, narcissism and identity politics', in L Snyder, BJ

Brueggemann and R Garland-Thomson (eds), Disability studies: enabling the humanities, New York, NY: Modern Language Association of America, 40-55.

Skeggs, B 1997, Formations of class and gender: becoming respectable, London: Sage.

Skeggs, B 2004, Class, self, culture, London: Routledge.

Smith, B 2004, 'The social underpinnings of an "outstation movement" in Cape York Peninsula, Australia', in J Taylor and M Bell (eds), Population mobility and Indigenous peoples in

Australasia and North America, London: Routledge, 239-261.

Smith, K 2003, 'Pushing the boundaries: the exclusion of disability rights groups from political influence in Victoria', Australian Geographer, 34 (3), 345-354.

Smith, LT 1999, Decolonising methodologies: research and Indigenous peoples, London: Zed Books.

Snyder, S and Mitchell, D 2006, Cultural locations of disability, Chicago, IL: University of Chicago Press.

Soldatic, K 2013, 'Appointment time: disability and neoliberal temporal rationalities', Critical Sociology, 39, 405-419.

Soldatic, K 2015, 'Postcolonial reproductions: disability, indigeneity and the formation of the white masculine settler state of Australia', Social Identities: Journal for the Study of Race, Nation and Culture, 21 (1), 53-68.

Soldatic, K 2018, 'Neoliberalising disability income reform: what does this mean for Indigenous Australians living in regional areas?' in D Howard-Wagner, M Bargh and I Altimarino-Jimenez (eds), Indigenous rights, recognition and the state in the neoliberal age, Canberra, ACT: ANU E Press.

Soldatic, K and Biyanwila, J 2006, 'Disability and development: a critical southern standpoint on able-bodied masculinity', presented at The Sociological Association Conference Proceedings, University of Western Australia, Perth, 3-7 December .

Soldatic, K and Chapman, A 2010, 'Surviving the assault? The Australian disability movement and the neoliberal workfare state', Social Movement Studies, 9 (2), 139-154.

Soldatic, K and Fiske, L 2009, 'Bodies locked up: intersections of disability and race in Australian immigration', Disability \& Society, 24 (3), 289-301.

Soldatic, K and Meekosha, H 2012, 'Disability and neoliberal state formations', in N Watson , C Thomas and A Roulstone (eds), Routledge handbook of disability studies, London: Routledge, Chapter 15.

Soldatic, K and Morgan, H 2017, "The way you make me feel": shame and the neoliberal governance of disability welfare subjectivities in Australia and the UK', in J Louth and M Potter (eds), Edges of identity: the production of neoliberal subjectivities, Chester: University of 
Chester Press, 106-133.

Soldatic, K and Pini, B 2012, 'Continuity or change? Disability policy and the Rudd government', Social Policy \& Society, 11 (2), 183-196.

Soldatic, K and Sykes, K 2017, 'Poverty and people with a disability', in K Serr (ed), Thinking about poverty, Sydney, NSW: Federation Press, 189-207.

Soldatic, KM , Spurway, K and Meekosha, H 2014, Hard yakka: living with a disability in the West Kimberley, Sydney, NSW: UNSW Australia.

Spurway, K and Soldatic, K 2015, "'Life just keeps throwing lemons": the lived experience of food insecurity among Aboriginal people with disabilities in the West Kimberley', Local

Environment, 21 (9), 1118-1131.

Stainton, T 2002, 'Taking rights structurally: disability, rights and social worker responses to direct payments', British Journal of Social Work, 32 (6), 751-763.

Steedman, C 1985, Landscape for a good woman, London: Virago.

Stoler, AL 2010, Carnal knowledge and imperial power: race and the intimate in colonial rule, Oakland, CA: University of California Press.

Stone, D 1981, The disabled state, Philadelphia, PA: Temple University Press.

Tarrow, S 1993, 'Cycles of collective action: between moments of madness and the repertoire of contention', Social Science History, 17 (2), 281-307.

Taylor, J and Bell, M 2004, 'Continuity and change in Indigenous Australian population mobility', in J Taylor and M Bell (eds), Population mobility and Indigenous peoples in Australasia and North America, London: Routledge, 13-43.

Thomas, C 1999, Female forms: experiencing and understanding disability, Buckingham: Open University Press.

Thomas, C 2002, 'Disability theory: key ideas, issues and thinkers', in C Barnes, M Oliver and L Barton (eds), Disability studies today, Cambridge: Polity Press.

Thomas, C 2004, 'How is disability understood? An examination of sociological approaches', Disability \& Society, 19 (6), 569-583.

Thomas, C 2007, Sociologies of disability and illness, Houndmills: Palgrave Macmillan. Thomas, S 2005, 'Taking teachers out of the equation: constructions of teachers in education policy documents over a ten-year period', The Australian Educational Researcher, 32 (3), 45-62.

Thompson, EP 1963, The making of the English working class, New York, NY: Vintage Books. Thornton, P 2005, 'Disabled people, employment and social justice', Social Policy \& Society, 4 (1), 65-73.

Tierney, J 2001, Newman to hand over portfolio to Vanstone, ABC, www.abc.net.au/7.30/stories/s234711.htm [accessed 25 March 2007 ].

Tilly, C 1978, From mobilisation to revolution, Reading: Addison-Wesley.

Tilly, C 2006, Regimes and repertoires, Chicago, IL: University of Chicago Press.

Tonts, M , Plummer, P and Lawrie, M 2012, 'Socio-economic wellbeing in Australian mining towns: a comparative analysis', Journal of Rural Studies, 28, 288-301.

Tremain, S (ed) 2005, Foucault and the government of disability, Ann Arbor, MI: University of Michigan Press.

Tucker, K 1991, 'How new are the new social movements?', Theory, Culture \& Society 8 (2), 75-98.

Tyler, I 2013, Revolting subjects, London: Zed Books.

Tyler, I 2015, 'Classificatory struggles: class, culture and inequality in neoliberal times', Sociological Review, 63 (2), 493-511.

Vanstone, A 2002, Queensland raid catches welfare fraudsters, media release, 5 February, https://formerministers.dss.gov.au/431/media_r_05022002/ [accessed 7 February 2018 ].

Vanstone, A 2003, More welfare cheats caught, media release, 2 October, www.fachsia.gov.au/internet/minfacs.nsf/549ed30c27024062ca2569e900837d9c/4c632e8582a 18fdcca256db40016822c?OpenDocument [accessed 30 October 2007 ].

Vanstone, A and Abbott, T 2001, Australians working together - helping people to move forward - a \$1.7 billion fair deal, media release, 21 May, Canberra, ACT: Australian Government.

Vike, H 1997, 'Reform and resistance: a Norwegian illustration', in C Shore and S Wright (eds), Anthropology of policy: critical perspectives on governance and power, London: Routledge,

195-216. 
Walker, R and Wiseman, M 2003, 'Making welfare work: UK activation policies under new labour', International Social Security Review, 56 (1), 3-29.

Walter, M 2016, 'Social exclusion/inclusion for urban Aboriginal and Torres Strait Islander people', Social Inclusion, 4 (1), 68-76.

Walter, M and Saggers, S 2007, 'Poverty and social class', in B Carson , T Dunbar, R Chenall and R Bailie (eds), Social determinants of Indigenous health, Sydney, NSW: Allen \& Unwin.

Watson, I 2012, 'The future is our past: we once were sovereign and we still are', Indigenous Law Bulletin, 8 (3), 12-15.

Wendell, S 1996, The rejected body: feminist philosophical reflections on disability, New York, NY: Routledge.

Wendell, S 2001, 'Unhealthy disabled: treating chronic illnesses as disabilities', Hypatia, 16 (4), 18-33.

White, S 2004, 'What is wrong with workfare?', Journal of Applied Philosophy, 21 (3), 271-284. Wilkin, P 1997, 'New myths for the South: globalisation and the conflict between private power and freedom', in C Thomas (ed), Globalisation and the South, New York, NY: St Martin's Press, 18-35.

Williams, F 1999, 'Good-enough principles for welfare', Journal of Social Policy, 28, 667-687. Wilson, H 1999, 'Time, space and value: recovering the public sphere', Time \& Society, 8 (1), 161-181.

Wilson, S and Turnbull, N 2001, 'Wedge politics and welfare reform in Australia', Australian Journal of Politics and History, 47 (3), 384-402.

Wilton, R 2004, 'From flexibility to accommodation? Disabled people and the reinvention of paid work', Transactions of the Institute of British Geographers, 29 (4), 420-432.

Wolch, J and Deverteuil, G 2001, 'New landscapes of urban poverty management', in J May and N Thrift (eds), Timespace: geographies of temporality, London: Routledge, 149-168. Wood, E 1995, Democracy against capitalism: renewing historical materialism, Cambridge: Cambridge University Press.

Wyndham, D 2003, Eugenics in Australia: striving for national fitness, London: The Galton Institute.

Yeatman, A (ed) 1990, Activism and the policy process, Sydney, NSW: Allen \& Unwin. Young, I 1990, Justice and the politics of difference, Princeton, NJ: Princeton University Press. Yuval-Davis, N 2007, 'Intersectionality, citizenship and contemporary politics of belonging', Critical Review of International Social and Political Philosophy, 10 (4), 561-574.

Zames Fleischer, D and Zames, F 2001, The disability rights movement: from charity to confrontation, Philadelphia, PA: Temple University Press.

Zitzelsberger, $\mathrm{H}$ 2005, '(In)visibility: accounts of embodiment of women with physical disabilities and differences', Disability \& Society, 20 (4), 389-403. 